\title{
WestVirginiaUniversity
}

THE RESEARCH REPOSITORY @ WVU

Volume 116 | Issue 1

Article 7

September 2013

\section{Out of the Shadows: Requiring Strategic Management Disclosure}

Nadelle Grossman

Marquette University School of Law

Follow this and additional works at: https://researchrepository.wvu.edu/wvlr

Part of the Administrative Law Commons, and the Securities Law Commons

\section{Recommended Citation}

Nadelle Grossman, Out of the Shadows: Requiring Strategic Management Disclosure, 116 W. Va. L. Rev. (2013).

Available at: https://researchrepository.wvu.edu/wvlr/vol116/iss1/7

This Article is brought to you for free and open access by the WVU College of Law at The Research Repository @ WVU. It has been accepted for inclusion in West Virginia Law Review by an authorized editor of The Research Repository @ WVU. For more information, please contact ian.harmon@mail.wvu.edu. 


\title{
OUT OF THE SHADOWS: REQUIRING STRATEGIC MANAGEMENT DISCLOSURE
}

\author{
Nadelle Grossman*
}

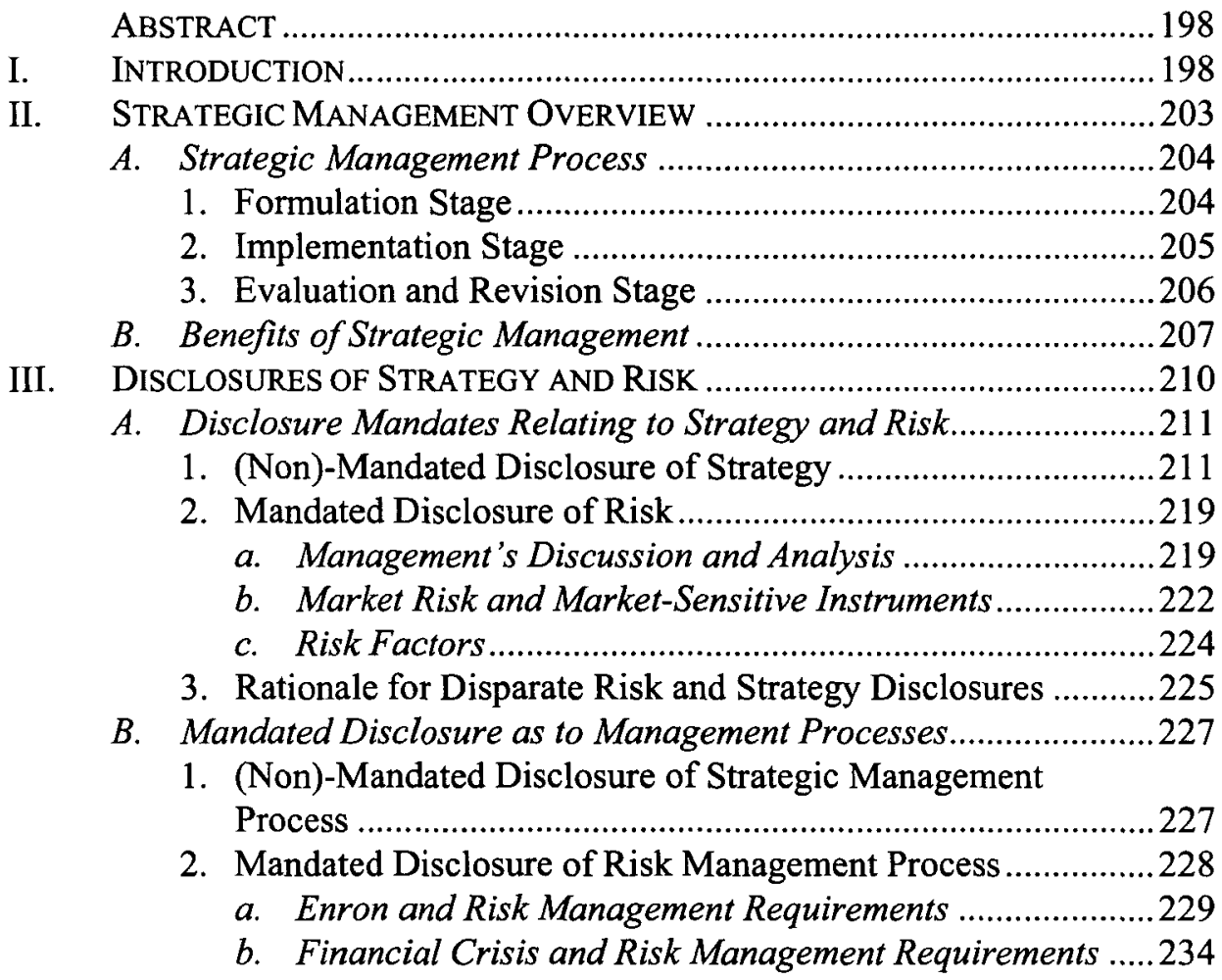

IV. SPURRING StRATEgIC MANAGEMENT THROUGH SECURITIES LAWS ..237

A. Concerns with Lopsided Disclosure of Risk and Strategic Management

\begin{abstract}
* Assistant Professor, Marquette University Law School. I would like to thank Ed Fallone, Kali Murray, Michael O'Hear, and David Orozco for their invaluable input on this article. In addition, I would like to thank participants of the 2012 Midwest Law and Economics Association Annual Meeting for their input. I would also like to thank Jeff Benson, Ryan Kehl, Michael Koutnik, Emily Krambs, Francisco (Paco) Quiroz, and Drew Walgreen for their excellent research assistance in connection with this and related articles. Finally, I would like to thank my family for their love and support throughout the research and writing process.
\end{abstract}


v.

\section{ABSTRACT}

Under federal securities laws and regulations, public companies must disclose to investors a considerable amount of information about their risk management processes to limit losses. In contrast, these companies need not disclose virtually anything about their strategic management processes to generate gains. This mismatch in disclosure gives investors a distorted sense of firm processes to create value, undermining the federal securities laws' central purpose of creating informed investors. It also signals that risk management processes, which are cast in disclosure sunlight, are more important to firm success than strategic management processes, which remain in the shadows.

To address these concerns, I propose that public firms be required to disclose those qualities of their strategic management processes that are equivalent to what those firms disclose about their risk management processes. I also propose that firms disclose how those two processes work together to create value. This new disclosure would encourage firms to design and implement their risk and strategic management processes in an integrated, holistic fashion, consistent with Enterprise Risk Management. It would also reinforce the reality that the path to long-term success for a firm lies not merely with managing its risks, but also with formulating and implementing an effective strategy for growth-a process that unfortunately may suffer from neglect amidst the boxchecking exercise that flows from compliance with scores of risk-based regulations.

\section{INTRODUCTION}

Apple Inc.'s revival is fabled. Despite almost going bankrupt in 1996, Apple is averaging roughly $\$ 4$ billion in profits a month. ${ }^{1}$ In addition, it is expected to continue to grow by taking advantage of several new technological trends. $^{2}$

How has Apple done it? How has it transformed itself into a successful company that consistently creates, markets, and sells innovative new products?

1 Sam Gustin, Why Apple Is Winning: Innovation, Opportunity and Execution, TIME (Apr. 25, 2012), http://business.time.com/2012/04/25/why-apple-wins-innovation-opportunity-andexecution/.

2 Id. 
Many business experts attribute Apple's success in part to its ability to innovate alongside its ability to effectively execute its business strategy. ${ }^{3}$ Specifically, "[a]t Apple there is never any confusion as to who is responsible for what." This "accountability mindset," coupled with a simple organizational structure that is fashioned around function rather than division, allows Apple to act nimbly to develop innovative responses to new business opportunities."

Despite the important role executing a strategy can play in a firm's success, many companies give this aspect of their strategic management process short shrift. In fact, according to numerous business commentators, one of the primary reasons why companies fail is that they devote insufficient resources to executing their strategies. ${ }^{6}$

Companies languish not only because they fail to effectively execute their strategies, but also because they fail to adopt effective strategies at the outset. ${ }^{7}$ Adopting a flawed strategy is another result of a defective strategic management process. For example, while Research in Motion Ltd. (RIM) once dominated the U.S. smart phone market, recently it has suffered a series of embarrassments, including a disastrous launch of its tablet and delayed shipment of its new Blackberry smartphone. ${ }^{8}$ These disasters were due in part to RIM's failure, in setting its strategy, to commit to a consumer base-corporate or individual users. ${ }^{9}$ As a result, RIM's products and marketing message were schizophrenic, inevitably leading to a strategy that has been ineffectual at preserving the company's competitive position. ${ }^{10}$

3 See, e.g., Chris Morrison, How to Innovate Like Apple, CBS MONEYWATCH (Aug. 10, 2009, 3:00 AM), http://www.cbsnews.com/8301-505125_162-51330240/how-to-innovate-likeapple/.

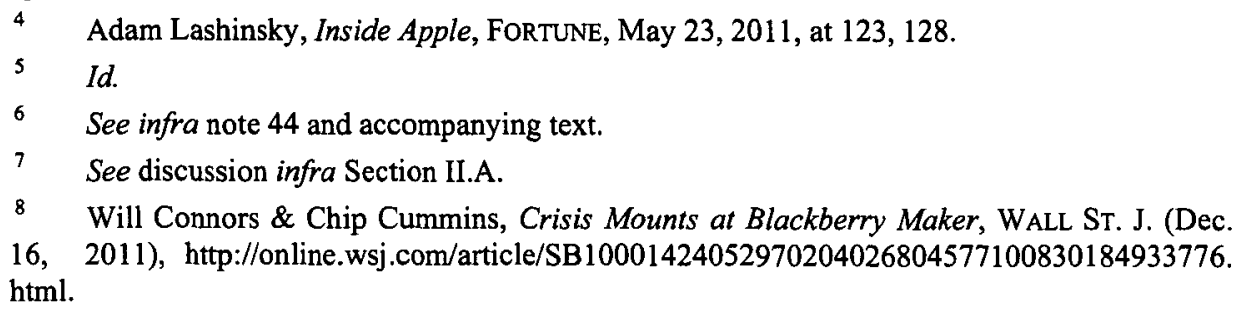

$9 \quad$ Phred Dvorak et al., Blackberry Maker's Issue: Gadget for Work or Play?, WALL ST. J. (Sept. 30, 2011), http://online.wsj.com/article/SB1000142405297020442240457659706159 1715344.html.

10 See Ian Austen, Blackberry 10 Critical to Research in Motion, N.Y. TIMEs, Jan. 29, 2013, http://www.nytimes.com/2013/01/30/technology/blackberry-10s-debut-is-a-critical-day-forresearch-in-motion.html?_r=0\&adxnnl=1\&ref=ianausten\&adxnnlx=1381933090-

$\mathrm{j} 2 \mathrm{Q} / \mathrm{eFSNA08bWqneOnHY/A}$ (noting that in 2012, RIM increased its consumer base through sales of low-cost handsets to consumers in developing countries, but that those consumers will not be able to afford RIM's new phones with the Blackberry 10 operating system, and that it will be costly and time-consuming for RIM to convince corporate users to switch to the new phone); Ian Austen, In Setback, RIM Delays Blackberry's Next Version, N.Y. TIMES, Jun. 28, 2012, http://www.nytimes.com/2012/06/29/technology/blackberry-maker-rim-posts-518-million- 
Securities laws are a driving force in firms' neglect of these strategic management processes. That is because securities laws virtually ignore this critical firm process. In particular, securities laws do not require reporting firms to disclose anything about the processes through which they formulate, execute, or revise their strategies, together referred to as their strategic management processes. ${ }^{11}$ In contrast, federal securities laws increasingly call for a host of information about firm processes to protect value through managing downside risk. ${ }^{12}$ For example, on the heels of the financial crisis, the SEC passed a rule requiring public firms to disclose the role of their boards in overseeing firm processes for managing risk. ${ }^{13}$ Because no such disclosure is required about the board's role in overseeing the firm's management of its strategy, investors are left trying to estimate a firm's value, as well as judge management's effectiveness, from information about risk and risk management processes.

This mismatch in treatment of strategic management and risk management carries over from legal mandates to academic scholarship. In particular, there is much academic commentary on risk management, and the need for improved processes to manage risk. ${ }^{14}$ In contrast, except for a prior article I wrote, ${ }^{15}$ there is virtually no on-going academic discussion about using the law to enhance firms' management of their strategies. The dearth of such a public

loss.html (noting that analysts are skeptical about RIM's ability to survive and that RIM is currently conducting a strategic review).

11 See discussion infra Section III.B.1.

12 See discussion infra Section III.B.2.

13 See infra note 223 and accompanying text.

14 See, e.g., Stephen M. Bainbridge, Caremark and Enterprise Risk Management, 34 J. CoRP. L. 967, 982 (2009) (stating that an effective risk management program can prevent risks from occurring and limit the impact of risks that occur); Robert T. Miller, Oversight Liability for RiskManagement Failures at Financial Firms, 84 S. CAL. L. REv. 47, 87-102 (2010) (illustrating the importance of risk management by using Citigroup's financial struggles during the 2008-09 subprime mortgage crisis as an example of risk management failure); Eric J. Pan, Rethinking the Board's Duty to Monitor: A Critical Assessment of the Delaware Doctrine, 38 FLA. ST. U. L. REV. 209, 216-17 (2011) (arguing that risk management is a corporate governance issue and that a board's fiduciary duty to monitor should be more robust so as to require investment in risk management systems); Betty Simkins \& Steven A. Ramirez, Enterprise-Wide Risk Management and Corporate Governance, 39 LOY. U. CHI. L.J. 571, 583-84 (2008) (stating that enterprisewide risk management can enhance firm value partly because securities rating services, including Moody's and S\&P, have started to incorporate risk management into their ratings methodology).

15 See generally Nadelle Grossman, The Duty to Think Strategically, 73 LA. L. REV. 449 (2013). A number of commentators have written articles discussing aspects of the law and strategy. For example, several articles discuss how law compliance can give a firm a competitive advantage. See, e.g., Constance E. Bagley, What's Law Got to Do With It?: Integrating Law and Strategy, 47 AM. BUs. L.J. 587 (2010); George J. Siedel \& Helena Haapio, Using Proactive Law for Competitive Advantage, 47 AM. BUS. L.J. 641 (2010). However, because these articles do not focus on the strategic management process, they fall outside of the scope of papers I refer to here. 
discourse of strategic management in the legal academy punctuates the law's silence on the topic and spares policy-makers from having to explain why securities mandates ignore such a critical organizational function as strategic management.

The mismatch in treatment of strategic and risk management processes is concerning for a number of reasons. First, it undermines one of the primary purposes of the federal securities laws, which is to protect investors and prospective investors by ensuring that they receive complete, timely, and accurate information about public firms. ${ }^{16}$ It is hard to argue that investors are completely informed about public firms when those firms are free to not even mention the existence of processes to create gains. In fact, the absence of such disclosure, coupled with information about processes to manage risk, could give investors a misleading picture into firm processes to create value. ${ }^{17}$

In addition, the absence of disclosure of processes to manage strategy, especially as compared to processes to manage risk, inevitably leaves boards and officers with the impression that the former is more important than the latter. That, in turn, leads them to devote more resources to risk-based processes that are cast in sunlight and fewer resources to strategic-based processes that remain in the shadows. ${ }^{18}$ This is particularly troubling, as the path to long-term success for firms lay not merely with managing risk of loss, but also with engaging in the companion exercise of formulating and executing an effective strategy for innovation and growth. Moreover, there is a risk that boards and officers are so tied up checking boxes to comply with risk-based regulations that they simply do not have time to create and execute on an effective strategy for growth.

To address these and related concerns, I propose that the SEC require public firms to disclose those aspects of their strategic management processes equivalent to what firms disclose about their risk management processes. In addition, firms should have to disclose how their risk and strategic management processes work together so that investors are able to better understand the connection between the two and how they together create firm value.

For example, under my proposal, firms would need to not only disclose the role of their boards in overseeing the management of risk, as they currently

16 See Securities Act of 1933, Pub. L. No. 22, 48 Stat. 74 (1933) (“An Act to provide full and fair disclosure of the character of securities sold in interstate and foreign commerce and through the mails, and to prevent frauds in the sale thereof ....") (emphasis added); Securities Exchange Act of $1934 \S 2,15$ U.S.C. $\S 78 \mathrm{~b}$ (2012) ("[T]ransactions in securities as commonly conducted upon securities exchanges and over-the-counter markets are affected with the national public interest which makes it necessary to provide for regulation and control of such transactions ... including ... to insure the maintenance of fair and honest markets in such transactions."); see also Susanna Kim Ripken, The Dangers and Drawbacks of the Disclosure Antidote: Toward a More Substantive Approach to Securities Regulation, 58 BAYLOR L. REV. 139, 150-51 (2006).

17 See discussion infra Section IV.A.

18 See discussion infra Section IV.A. 
must do, ${ }^{19}$ but also the role of their boards in overseeing the management of strategy. Moreover, firms would have to disclose how each of these functions affected the board's performance of the other function.

While there is some hope that firms already effectively formulate and execute on their strategies, and that accountability to investors through mandated disclosure is not necessary, that same argument would also seem to counter the need for disclosure of risk management processes, as both processes aim at creating value. Yet, recent events have revealed the absence of adequate risk management despite the apparent incentive to already engage in an effective process. In fact, strategic management, just like risk management, is vulnerable to manipulation by short-term thinkers, who focus more on meeting or beating earnings forecasts than creating sustained value. ${ }^{20}$ Moreover, the numerous instances of defective strategic management processes ${ }^{21}$ belie their proper functioning. Thus, disclosure of strategic management processes can help investors ensure that the firms they invest in are being operated in a way designed to create sustained value, in addition to providing them with valuable information for valuation and accountability purposes.

The rest of this article proceeds as follows: first, Part II provides an overview of strategic management, including how that process relates to risk management. That discussion also reveals the benefits to firms of engaging in strategic management in their search for wealth creation. Next, Part III discusses the impact of securities laws on firms' management of strategy and risk. That discussion considers legal requirements not only on strategic and risk management processes, but also on substantive disclosure of strategy and risk, for such substantive disclosure inevitably underlies the design of firm processes to manage strategy and risk. As that discussion shows, public firms are required to make substantial disclosures as to their risk and processes to manage risk. In contrast, they need not disclose virtually anything at all about their strategies or processes to manage strategy. While there are good reasons to not require firms to disclose their strategies, including the need to protect the secrecy of such plans from competitors, as I argue in Part IV, the same arguments do not necessarily preclude disclosure about strategic management processes. And, providing a more balanced picture of firm processes to create value could signal to managers and directors that strategic management processes are as important to value-creation as risk management. Thus, as I propose in Part IV,

\footnotetext{
19 See infra note 223.

20 See Judith F. Samuelson \& Lynn A. Stout, Op-Ed., Are Executives Paid Too Much?, WALL ST. J., Feb. 26, 2009, at A13, available at http://online.wsj.com/article/ SB123561746955678771.html (arguing that one of the causes of myopia is investors' preoccupation with quarterly earnings forecasts and short-term share price changes, given their inability "to gauge whether a company is making sound, long-term investments by training employees, improving customer service, or developing promising new products").

21 See discussion infra Part II.A.
} 
the SEC should mandate that public firms disclose information about their strategic management processes that correspond with information provided about risk management processes and explain how those two processes operate together to create firm value.

\section{Strategic MANAGEMENT OVERVIEW}

A business must innovate to survive over time. ${ }^{22}$ Yet innovation cannot happen without management systems designed to foster that innovation and turn it into value. ${ }^{23}$ Strategic management is one of these key management systems. ${ }^{24}$ More generally, strategic management refers to the process of managing a firm in a way that maintains its competitiveness. ${ }^{25}$ Managing a firm strategically is critical to its survival in a market economy, as competitors are always on the look-out for ways to increase their market share, even at the expense of their competitors. ${ }^{26}$ As a result, a firm must always have its eyes set on the future, and have in place a process that guides it down the path toward sustained wealth creation.

Many business commentators describe a three-stage process for strategic management: first, the formulation stage; second, the implementation or execution stage; and third, the review and revision stage. ${ }^{27}$ Section A discusses each of these stages. Section A also explains the essential role risk management plays in managing a firm's strategy. Then, Section B explains the benefits to a firm of effectively managing its strategy. ${ }^{28}$

\footnotetext{
22 Tony Davila et al., Making InNovation Work: How to Manage It, Measure IT, AND PROFIT FROM IT 6 (2006).

23 Id. at 119.

24 Bruce R. Barringer \& Allen D. Bluedorn, The Relationship Between Corporate Entrepreneurship and Strategic Management, 20 STRATEGIC MGMT. J. 421, 421 (1999) ("Among the management practices believed to facilitate entrepreneurial behavior are a firm's strategic management practices.").

\section{See Grossman, supra note 15 , at 456.}

26 Id. For a discussion of frameworks that firms use to analyze the source of their competitive advantage, see id. at 459-61. See also Norman D. Bishara \& David Orozco, Using the ResourceBased Theory to Determine Covenant Not to Compete Legitimacy, 87 IND. L. J. 979, 1009-10 (2012) (explaining the resource-based theory of competitive advantage, which attributes a firm's sustained competitive advantage to its unique resource position).

27 Grossman, supra note 15 , at 456-57. In reality, there is often no clear demarcation between these stages, and these stages are performed along a continuum rather than in discrete steps. However, it is useful to think of strategic management in stages to better understand the different components of the process, as well as to see how each component of the process enhances a firm's ability to compete.

28 This discussion is an abbreviated review of strategic management processes, which I explained in more detail in a prior article. $I d$. at $455-73$. In the prior article, I argued that officers and directors should have a fiduciary duty to oversee a firm's strategic management process. Id.
} 


\section{A. Strategic Management Process}

\section{Formulation Stage}

The first stage of strategic management is the formulation stage. ${ }^{29}$ During this stage, planners formulate qualitative and quantitative objectives for the firm to achieve over the long-term. ${ }^{30}$ Planners at this stage also formulate a strategy —or roadmap - for achieving those qualitative and quantitative objectives in light of the firm's competitive advantage and environment, its weaknesses, its resources and other constraints, and potential future threats and opportunities, all while taking into account the desired level of, and tolerance for, risk. $^{31}$

The management of risk plays an important role in the formulation stage, for managers cannot select an optimal strategy without identifying, assessing, and measuring the risk effects of potential strategies. ${ }^{32}$ However, the formulation of strategy is by no means limited to the consideration of risk. Rather, managers must consider everything that can impact a firm's competitiveness, from its strengths to its weaknesses, among other things, in creating a strategic plan. ${ }^{33}$ Therefore, while risk-based considerations are an important determinant of a firm's strategy, they alone do not dictate a firm's strategic choice.

There are numerous pitfalls that belie firms in the formulation phase. According to numerous academic commentators, one hazard that undermines the effectiveness of a firm's planning efforts is the failure to get everyone involved who should be involved in creating a plan. ${ }^{34}$ For example, a company might fail to include lower-level managers in its planning, which could lead senior executives to adopt a plan that is simply unrealistic for lower-level employees to implement. ${ }^{35}$

at 508. This article complements that proposal by suggesting how federal securities laws can be changed to ensure shareholders receive more information about a firm's strategic management process. With this information, shareholders would be better able to enforce such board duties.

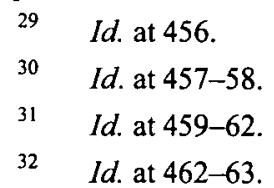

33 See supra note 31 and accompanying text.

34 See Lawrence G. Hrebiniak, Obstacles to Effective Strategy Implementation, 35 ORGANIZATIONAL DYNAMICS 12, $13 \quad$ (2006), available at http://www.sciencedirect.com/science/article/pii/S0090261605000677 (All levels of management from "C-level managers on down must commit to and own the strategy.").

35 See Harv. Bus. Sch. Press \& Soc'y for Human Res. Mgmt., The Essentials of STRATEGY 109-10 (2006) ("Every manager and every employee in a company-from the execu- 
GM exemplifies another common hazard of the formulation stage. For years, GM failed to revise its strategy to respond to emergent competition from foreign companies. ${ }^{36}$ Instead, GM blindly assumed for planning purposes that the entry of foreign competitors into the U.S. car market was only temporary, and that customers would stick with the GM brand despite having an inferior and more expensive product. ${ }^{37}$ Making such unreasonable assumptions about the future undermines the effectiveness of a firm's planning efforts, for that process depends on the making of realistic assumptions about the future based on all available information. ${ }^{38}$ Without being based on realistic, informed assumptions, a firm's strategic plan is simply not worth the paper it is written on.

\section{Implementation Stage}

The next stage in the strategic management process is the strategy implementation stage. ${ }^{39}$ In this stage, employees throughout a firm-from the highest executives to the employees in the deepest recesses of the firm-make decisions and discharge tasks in furtherance of the selected strategy. ${ }^{40}$ Because employees throughout a firm are charged with implementing strategy, all managers, including lower-level managers, supervise some aspect of implementation. ${ }^{41}$

Here, too, the management of risk plays an important role, for a firm must implement measures to respond to risks that crop up while the strategy is being implemented. ${ }^{42}$ In addition, a firm must have a control system in place to identify and communicate to top management where the firm skips its tracks in terms of implementation. ${ }^{43}$ Yet here, again, risk management does not alone set out a framework for the implementation of strategy. Rather, it bolsters the process to help the firm create value.

Companies experience many challenges at this stage, too. In particular, numerous commentators have found that firms often devote insufficient resources to the implementation of their strategies. ${ }^{44}$ As a result, firms are often

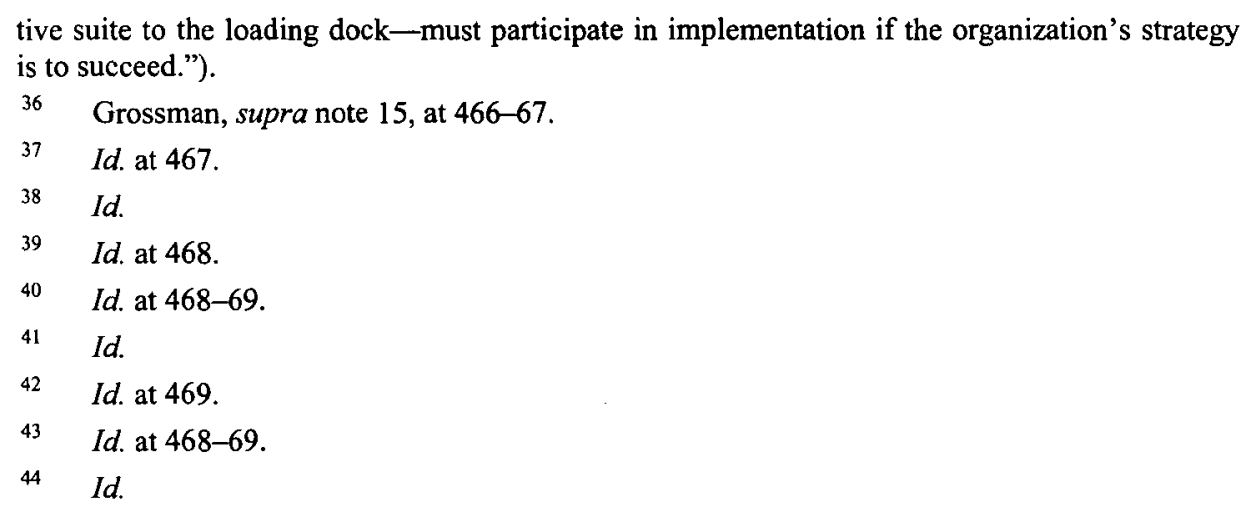


ineffective at implementing their strategies, realizing only a fraction of the value they might otherwise realize from their plans. ${ }^{45}$

\section{Evaluation and Revision Stage}

Finally, in the third stage of strategic management, managers evaluate whether the firm is successfully implementing its strategy and is marching down a path toward achieving its objectives. ${ }^{46}$ If a firm's strategy is not effectively leading the firm toward its objectives, planners must reformulate the strategy, or the firm's objectives, or both, so that it does. ${ }^{47}$ Moreover, as the future comes to pass, a firm might be presented with new opportunities and face new threats. ${ }^{48}$ These changed circumstances might also call for a change in a firm's strategic plan. ${ }^{49}$

As with the other stages in strategic management, the evaluation and revision of firm strategy can only be effective when it occurs alongside a properly functioning risk management process, for it is the latter process that helps a firm identify the emergence of new risks. ${ }^{50}$ That process, then, feeds information about risks back into the strategic management process so that a firm's strategic plan can be properly evaluated and revised as necessary. ${ }^{51}$ Yet as with the other strategic management stages, the management of risk does not alone set out a framework for the revision of strategy.

At this stage, too, strategic management scholars have found firm processes lacking. In particular, they have found that companies often collapse because of their failure to adapt their plans to changed circumstances. ${ }^{52}$ In addition to its earlier discussed failure at the formulation stage, GM is often cited as an example of failure at the revision stage. Specifically, GM failed to modify its strategy to address a new competitive landscape after foreign car

\footnotetext{
$45 \quad I d$.

$46 \quad$ Id. at 470 .

47 Id. at 471 .

$48 \quad I d$.

49 Id.

so While the term "risk" technically includes up-side risk, or the possibility that returns will be greater than expected, as well as down-side risk, or the possibility that returns will be lower than expected, most legal commentators view risk solely in its down-side sense. Id. at 462 . Moreover, as the discussion in Part III shows, for purposes of federal securities laws, the term "risk" is typically thought to only refer to down-side risk.

$51 \quad$ Id. at 471.

52 Id. at 472. Another pitfall at this stage is a firm's failure to provide to the board and managers the information they need to determine whether the firm is achieving non-financial goals. See David Larcker \& Brian Tayan, Corporate Governance MatTers: A Closer look at ORganizational ChoICES AND TheIR CONSEQUENCES 185 (FT Press 2011).
} 
manufacturers began selling cheaper, more fuel-efficient cars in the U.S. ${ }^{53}$ As a result, over time, GM's strategy-once driving it down a path toward immense profitability-left GM at the brink of insolvency and in need of a substantial infusion of taxpayer money for its very survival. ${ }^{54}$

Firms also fail at this stage by sticking with processes designed to listen to customers and their needs. ${ }^{55}$ Those processes, while accountable for a firm's initial success, often fail to nurture new technology. ${ }^{56}$ As a result, those firms may not be able to compete when presented with technological change. ${ }^{57}$

\section{B. Benefits of Strategic Management}

There are numerous benefits to engaging in a deliberate strategic management process.

For one, managing strategy causes a firm to be calculated and intentional in planning out its future. ${ }^{58}$ In that way, a firm takes control over its future, rather than merely succumbing to the unguided and uncoordinated decisions of its managers and employees.

Another benefit is that it helps a firm create useful benchmarks for purposes of incentivizing and rewarding its employees. ${ }^{60}$ In particular, because all firm efforts are supposed to be dedicated to the achievement of firm objectives, incentive compensation of managers and other employees can be tied to the achievement of those objectives, or sub-objectives, designed to lead the firm to achieve its overall objectives. ${ }^{61}$ Managerial compensation can also be tied to effective implementation of specific strategic steps. ${ }^{62}$

Managing a firm strategically also helps combat short-termism, or the drive to generate short-term results rather than sustained value. ${ }^{63}$ That is because a firm formulates and implements a strategic plan to map out and then pursue a path to create sustained value. ${ }^{64}$ As such, a firm with long-term objectives and a strategy to achieve those objectives might use those benchmarks, rather than the latest earnings forecast, to guide internal decisions and tasks.

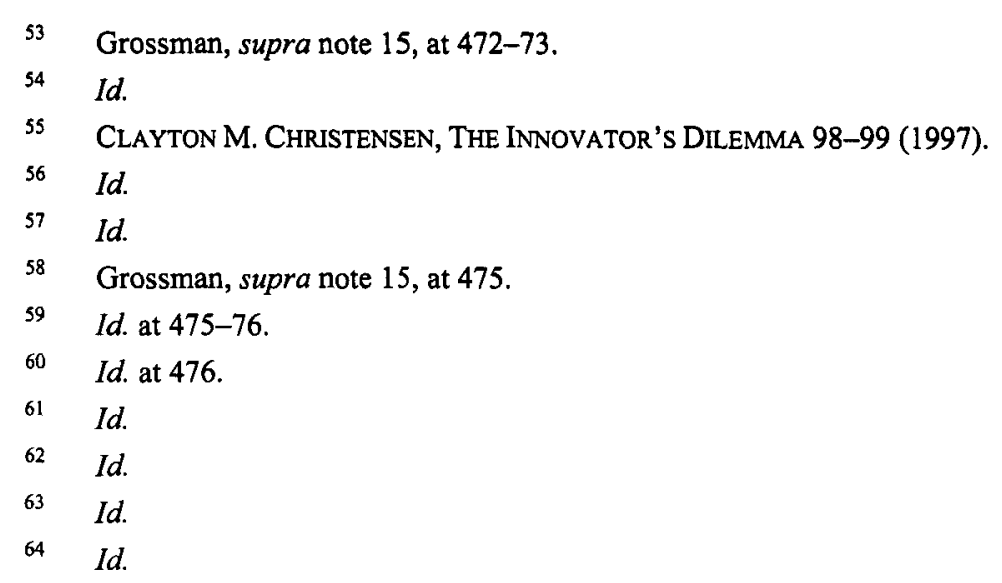


Still, strategic management is no panacea for short-termism. That is because there are a number of reasons why firms are myopic apart from deficient strategic management processes. In fact, firms might give short-shrift to strategic management efforts because of pressures on them to act myopically. ${ }^{65}$

One reason why firms act myopically is because their publicly disclosed information does not reflect their long-term values. ${ }^{66}$ For example, financial reporting obligations focus on past transactions rather than the sources of a firm's value going forward. ${ }^{67}$ Additionally, reporting obligations are largely tied to accounting book value, which has very little to do with a firm's value. ${ }^{68}$ For instance, despite the fact that a firm's intangible assets, such as its patents and trademarks, contribute significantly to its value, under accounting rules the firm's investments in these assets must be expensed rather than capitalized. ${ }^{69}$ As a result, firms have an incentive to diminish their investments in these value-creating assets to increase their reported earnings. ${ }^{70}$ Thus, the shortterm information that firms provide might actually lead to more myopic practices.

Professor Lynne L. Dallas has advanced a number of thoughtful proposals to give investors a better sense for the value of a firm based on its riskadjusted expected future cash flows, for that is often the best way to calculate a firm's true value. ${ }^{71}$ However, as those proposals reflect, firms can only provide investors with so much information about their operations into the future without potentially risking the secrecy, and in turn value, of their strategic plans. ${ }^{72}$

Those same concerns do not, however, dictate a lack of transparency into strategic management processes, which is information that could help investors determine the level of firm commitment to processes to create sustained wealth. ${ }^{73}$ That information could, in turn, give investors some sense for a firm's wealth-creating potential without compromising the confidentiality of its

\footnotetext{
65 See Nadelle Grossman, Turning a Short-Term Fling into a Long-Term Commitment: Board Duties in a New Era, 43 U. MICH. J. L. REFORM 905, 927-30 (2010).

66 See Lynne L. Dallas, Short-termism, the Financial Crisis and Corporate Governance, $37 \mathrm{~J}$. CORP. L. 265, 324 (2011).

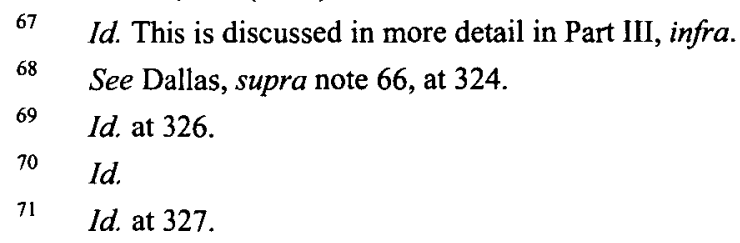

72 See id. (excluding any proposal that firms disclose their strategies, and instead supporting a proposal that would provide a statement of cash flows separately from that for cash flow accruals to provide investors with separate information on historic cash flows and projected cash flow prospects).

73 See discussion infra Part IV.A.
} 
strategy. ${ }^{74}$ Yet, as I show in the next Part, federal securities laws do not currently require disclosure of any aspect of firm processes to manage strategy. That might further feed investors' reliance on historic and short-term focused information for calculating a firm's wealth-generating potential.

Still, there are downsides associated with instituting a strategic management process. For one, to the extent a firm puts in place a rigid process, managers might not feel at liberty to diverge from that process. ${ }^{75}$ For example, managers might not feel open to identifying new opportunities outside of a firm's traditional business line. ${ }^{76}$ Thus, managers can, in a sense, become captured by the strategic management process. While this is indeed a risk, an effective, well-thought-out process should not be so rigid as to preclude the pursuit of new opportunities. ${ }^{77}$ In fact, the process should encourage the reconsideration of alternative strategies whenever an internal or external change warrants it. ${ }^{78}$

Similarly, where a firm has a strategic management process in place, managers might feel that the strategy that resulted from that process is set in stone. ${ }^{79}$ In a sense, managers might not be able to envision an alternate path. ${ }^{80}$ Once again, such over-attachment to a firm's current strategy can be combated by putting in place an effective system of strategy review and revision, that is triggered upon any change in the internal or external factors driving the firm's strategic choice. ${ }^{81}$ Thus, having an effective strategic management process could actually prevent such over-attachment that might otherwise occur without such a formalized process.

Another commonly expressed downside to instituting a formal strategic management process is that putting in place and implementing such a process can take time, energy, and resources, especially of top-level officers. ${ }^{82}$ However, these costs should be outweighed by the benefits of having in place a well thought-out process that hopefully leads to the firm's adoption and implementation of a winning strategy. ${ }^{83}$ That process, then, can complement managers' intuition and judgment, to lead to better decisions. ${ }^{84}$

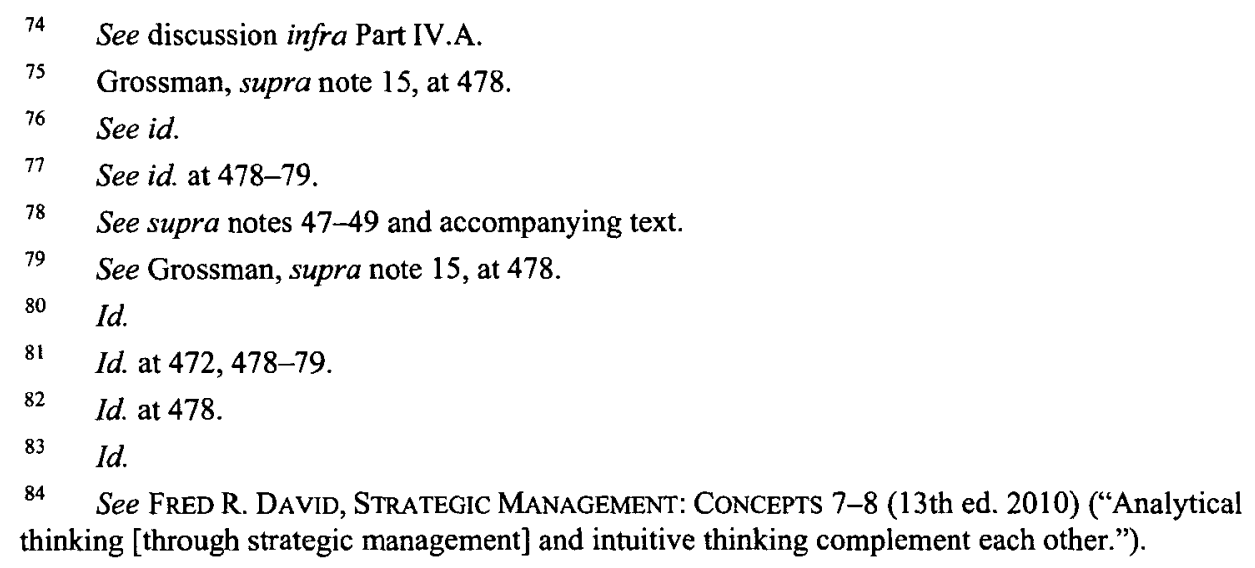




\section{DiSClOSURES OF STRATEGY AND RISK}

As the preceding discussion explained, a strong, interdependent relationship exists between risk and strategic management processes. That discussion also explained how both processes contribute to a firm's creation of value, where the former process focuses on protecting value and the latter process focuses on creating value by generating gains. Despite that integral relationship and singular purpose, risk and strategy, as well as the processes to manage risk and strategy, are treated quite dissimilarly under federal securities laws and the regulations implementing those laws (referred to together as the "securities mandates").

On the one hand, firms must disclose a litany of information about risk, as well as about their processes to manage risk. On the other hand, firms need not disclose virtually anything about their strategies, nor about their processes to manage their strategies. Further, securities mandates as to risk management do not even mention anything about the process of managing strategy, or its relationship to the management of risk.

While there are certainly reasons to not require firms to have to disclose their strategic plans-most importantly, because of the need to protect a firm's competitive advantage as reflected in its strategic choice ${ }^{85}$ - there are not similarly compelling reasons to protect the secrecy of firms' current strategic management processes. ${ }^{86}$ In fact, keeping such processes entirely confidential is problematic for many reasons, not least of which is the implication that strategic management processes are not as important as disclosed risk management processes. ${ }^{87}$

The rest of this Part reviews securities mandates relating to risk and strategy as well as their associated management processes. It focuses first on mandates relating to strategy and risk (Section $A$ ), exposing the absence of mandates on the disclosure of strategy compared to the litany of such mandates on the disclosure of risk. Section $\mathrm{A}$ also examines the rationale for requiring firms to disclose information about their risks but not their strategies. Then the discussion turns to securities mandates governing those management processes relating to strategy and risk (Section $B$ ). That discussion once again reveals the absence of mandates pertaining to strategic management, compared to the increasing disclosure mandates pertaining to risk management.

\footnotetext{
85 See infra notes $164-71$ and accompanying text.

86 See discussion infra Part IV.A.

87 See discussion infra Part IV.A.
} 


\section{A. Disclosure Mandates Relating to Strategy and Risk}

This Section explains what information firms must provide about their strategies and risks. It begins in Subsection 1 with a discussion of what public firms must disclose-or more appropriately, not disclose-about their strategies.

Still, firms are not limited to disclosing information required by securities mandates. Thus, it is possible that firms are not required to disclose their strategies because they already do so voluntarily. However, Subsection 1 dispels that notion by showing that there is great divergence among firms as to whether and how much of their strategies they disclose, with a trend of limited disclosure. Consequently, investors do not receive regularized information about firms' plans to create gains as a result of either legal mandates or voluntary disclosures.

The absence of regularized disclosure about strategy is then contrasted with the extensive information about risk that firms must provide under securities mandates. Those mandates are discussed in Subsection 2.

Subsection 3 then explains why this mismatch in information about risk and strategy is necessary in light of the competitive nature of U.S. firms, and the importance of secrecy to many firms' competitive advantage.

\section{1. (Non)-Mandated Disclosure of Strategy}

The primary goal of securities mandates is to protect investors and prospective investors by ensuring that they receive complete, timely, and accurate information about public firms. ${ }^{88}$ That disclosure is intended to enable investors and prospective investors to determine what a firm is worth so that they can make rational investment choices. ${ }^{89}$ Once an investment decision is made, disclosure also "assists shareholders in monitoring management and in proxy voting, which helps ensure that the projects that are undertaken are managed better."

Despite these laudable goals, by and large, securities mandates call for disclosure only of historic results and objective facts. ${ }^{91}$ In other words, securi-

\footnotetext{
88 See sources cited supra note 16.

89 See id.; see also Ripken, supra note 16, at 151 ("So long as corporations disclosed all material information about their operations and their securities, investors could make their own investment decisions.").

90 Luis A. Aguilar, Facilitating Real Capital Formation, THE HARV. SCH. F. ON CORP. GoverNANCE AND FIN. REG. (Apr. 23, 2011, 9:07 AM), http://blogs.law,harvard.edu/corpgov/2011/04/23/facilitating-real-capital-formation/\#more17391.

91 See Susanna Kim Ripken, Predictions, Projections, and Precautions: Conveying Cautionary Warnings in Corporate Forward-Looking Statements, 2005 U. ILL. L. REV. 929, 932 (2005).
} 
ties mandates tend to favor the disclosure of what is seen as "hard" information-or information that can be verified-rather than "soft" information. Soft information is typically thought to refer to projections, forecasts, estimates, opinions, intentions, and other information that involves some subjective analysis or prediction. ${ }^{93}$

Because a firm's strategy is essentially a statement of management's intention for the future, it falls directly in the ambit of the kind of soft information that need not be disclosed to investors. ${ }^{94}$ In fact, an exemption exists under the Freedom of Information Act that prevents private parties from having to disclose "financial or commercial data" to government agencies that would "cause substantial harm to the competitive position of the person from whom the information was obtained." 95 The SEC has applied this exemption to protect the confidentiality of firms' strategies. ${ }^{96}$

\footnotetext{
92 See id. In fact, until 1973, the SEC did not even allow the disclosure of "soft" information on the basis that it was inherently unreliable, and unsophisticated investors would fail to appreciate its uncertainty. See SEC. \& EXCH. COMM'N, DISClOSURE To INVESTORS-A REAPPRAISAL OF FEDERAL ADMINISTRATIVE POLICIES UNDER THE '33 AND '34 ACTS 95-96 (1969) (discussing policy against including projections and predictions in reports filed with the SEC and concluding that policy should not be changed).
}

93 See, e.g., Kohn v. Am. Metal Climax, Inc., 458 F.2d 255, 265 (3d Cir. 1972) (specifying that soft information includes "future earnings, appraised asset valuations and other hypothetical data"), cert. denied, 409 U.S. 874 (1972); H. COMM. ON INTERSTATE AND FOREIGN COMM., 95TH CONG., REP. OF THE ADVISORY COMM. ON CORP. Disclosure to tHE SEC. \& EXCH. COMM'N D-14 (Comm. Print 1977), available at http://c0403731.cdn.cloudfiles.rackspacecloud.com/ collection/papers/1970/1977_1103_AdvisoryDisclosure.pdf (noting the following as examples of soft information: "opinions, predictions, analyses and other subjective evaluations"). But see Bruce A. Hiler, The SEC and the Courts' Approach to Disclosure of Earnings Projections, Asset Appraisals, and Other Soft Information: Old Problems, Changing Views, 46 MD. L. REv. 1114, 1117 n.6 (1987) (citing to sources arguing that even historical information has some degree of subjectivity).

94 See Statement by the Commission on Disclosure of Projections of Future Economic Performance, Securities Act Release No. 5362, [1972-1973 Transfer Binder] Fed. Sec. L. Rep. (CCH) I 79,211 (Feb. 2, 1973); see àlso CVS Corp., SEC No-Action Letter, 2000 WL 141042 (Feb. 1, 2000) (determining that CVS could omit the shareholder proposal requesting disclosure of the company's goals, strategies, policies, and programs as a matter of ordinary business operations under Rule 14a-8(i)(7)). Courts tend to view "soft" information as not being material. See, e.g., Walker v. Action Indus., Inc., 802 F.2d 703, 709 (4th Cir. 1986), cert. denied, 479 U.S. 1065 (1987); Starkman v. Marathon Oil Co., 772 F.2d 231, 241-42 (6th Cir. 1985), cert. denied, 475 U.S. 1015 (1986); Pavlidis v. New England Patriots Football Club, Inc., 737 F.2d 1227, 1233 (1st Cir. 1984). But see Flynn v. Bass Bros. Enter., 744 F.2d 978, 988 (3d Cir. 1984) (holding that in certain circumstances, the court would require the disclosure of soft information).

95 Freedom of Information Act, 5 U.S.C. § 552(b)-(4) (2012); Nat'l Parks and Conservation Assoc'n v. Kleppe, 547 F.2d 673, 677-78 (D.C. Cir. 1976).

96 See, e.g., Fuel Tech, Inc., Annual Report (Form 10-K) (Mar. 5, 2009) (omitting information from a Restated Product Supply Agreement and noting that the company had requested confidential treatment for the omitted portions). The SEC used the $\S 552(\mathrm{~b})(4)$ Freedom of Information Act exemption to grant the confidential treatment request. Fuel Tech, Inc., SEC Con- 
Not only has the SEC expressly protected firms from needing to disclose their strategies, but it has also protected firms from needing to make such disclosure indirectly, such as through disclosure about executive compensation arrangements. For example, under new rules adopted by the SEC following the options back-dating scandal, every public firm must disclose in narrative form-in a section called Compensation Discussion and Analysis, or CD\&Athe material elements of its compensation program, such as the objectives underlying the firm's compensation program, and what each aspect of the program is designed to reward. ${ }^{97}$ An example of what constitutes a "material element" of a firm's compensation program includes information about "the basis for allocating compensation to each different form of award (such as relationship of the award to the achievement of the registrant's long-term goals ......". Another is information about "the specific items of corporate performance [that] are taken into account in setting compensation policies and making compensation decisions." 99

As the SEC acknowledged in passing this rule, a discussion of either of these elements could potentially reveal a firm's strategy. ${ }^{100}$ That is because if an employee covered by CD\&A received incentive compensation tied to the achievement of a confidential firm objective or implementation of a selected strategy, then a complete discussion of compensation would call for the disclosure of that objective or strategy. To address that concern, the SEC has specifically instructed that firms "are not required to disclose target levels with respect to specific quantitative or qualitative performance-related factors ... or any other factors or criteria involving confidential trade secrets or confidential commercial or financial information, the disclosure of which would result in competitive harm for the registrant." ${ }^{\text {"101 }}$ However the firm must disclose how difficult or likely it will be that the employee will achieve the undisclosed target. ${ }^{102}$ This exception to CD\&A reinforces the SEC's sensitivity to firms' need to protect the secrecy of their strategies, despite the countervailing policy in fa-

\footnotetext{
fidential Treatment Order (Mar. 19, 2009), available at http://www.sec.gov/Archives/edgar/data/846913/999999999709009042/9999999997-09-009042index.htm.

$97 \quad 17$ C.F.R. $\$ 229.402(\mathrm{~b})(1)(2013)$.

$98 \quad I d$. at $\S 229.402(\mathrm{~b})(2)(\mathrm{iii})$.

$99 \quad I d$. at $\S 229.402(\mathrm{~b})(2)(\mathrm{v})$.

100 Executive Compensation and Related Party Disclosure, Securities Act Release No. 8732A, Exchange Act Release No. 54,302A, Investment Company Act Release No. 27,444A, 71 Fed. Reg. 53,158, 53,166 (Aug. 29, 2006), available at http://www.sec.gov/rules/final/2006/338732a.pdf.

$101 \quad 17$ C.F.R. $\S 229.402$ Instruction 4 (2013); see also Interpretive Guidance on the Application of Item 402 of Regulation S-K, SEC No-Action Letter, 2007 WL 516136, at *2 (Jan. 14, 2007) [hereinafter Interpretive Guidance on the Application of Item 402].
}

102 Interpretive Guidance on the Application of Item 402, supra note 101. 
vor of keeping investors informed about matters that affect their investment and voting decisions.

Still, securities mandates do not limit what firms may disclose to their investors. In fact, the securities mandates are intended to serve as a baseline, rather than a limit, on what public firms disclose to their investors. ${ }^{103}$ Thus, one might surmise that securities mandates do not require the disclosure of strategy because firms already provide that kind of rosy information.

However, that is contrary to what I found in a non-scientific study of the reporting companies included in the 100 largest Fortune 500 firms. ${ }^{104}$ Specifically, in that study I found that approximately $35 \%$ of the largest reporting public companies provided little to no disclosure about their strategies in their annual reports, while an additional 34\% discussed some aspects of their strategies, but only within discussions focused on other topics.

Wal-Mart, the second largest company in the U.S. by revenue, ${ }^{105}$ exemplifies the limited nature of public discussion of firm strategy. In its 2011 Form 10-K, Wal-Mart disclosed only the following in terms of its strategic plan:

We employ many programs designed to meet competitive pressures within our industry. These programs include the following: EDLP - our commitment to price leadership and our pricing philosophy under which we price items at a low price every day so our customers trust that our prices will not change under frequent promotional activity. ... ${ }^{100}$

\footnotetext{
103 See Mary L. Schapiro, Chairman, U.S. Sec. \& Exch. Comm'n, Remarks at the NACD [National Association of Corporate Directors] Annual Corporate Governance Conference (Oct. 19, 2010), available at www.sec.gov/news/speech/2010/spch101910mls.htm ("For boards and their companies, engagement means more than just disclosure. It means clear conversations with investors about how the company is governed - and why and how decisions are made."). For example, former Chairman Schapiro highlighted that a statement that "risk is overseen by the board as a whole" is "not all that helpful" and more detailed disclosures help "investors feel better informed and reassured." Id.

104 In this non-scientific study, a research assistant reviewed the Form 10-Ks for fiscal year 2011 for all of the companies falling within my sample and coded the level of disclosure, where 1 equaled no disclosure of strategy (other than to state that the firm has one), 2 equaled some discussion of a firm's strategy is present, but is contained within a section in which strategy is not the primary focus, and 3 equaled explicit discussion of strategy in a section identified as a discussion of such. In the study, 33 companies were coded " 1, " 32 companies were coded " 2 ," and 28 companies were coded " 3 ." Of the 100 largest companies within the Fortune 500, 7 were nonreporting companies. Thus, the sample is comprised of 93 companies.

105 See Fortune 500, CNN MONEY, http://money.cnn.com/magazines/fortune/ fortune500/2012/full_list/ (last visited Sept. 6, 2013).

106 Wal-Mart Stores Inc., Annual Report (Form 10-K), at 6 (Mar. 30, 2011), available at http://www.sec.gov/Archives/edgar/data/104169/000119312511083157/d10k.htm.
} 
While this disclosure shows that Wal-Mart has a strategy designed to meet competitive pressures (identified as "programs"), it obviously does not tell the investor how it competes on the basis of low prices. ${ }^{107}$ Thus, Wal-Mart has chosen to keep its strategy confidential.

This sparing description of strategy contrasts with ExxonMobil Corporation's more extensive discussion of strategy. For example, in its 2011 Form10-K, ExxonMobil, the largest U.S. public company by revenue, ${ }^{108}$ stated that

[t]hese strategies [referring to its fundamental upstream strategies] include identifying and selectively capturing the highest quality exploration opportunities, maximizing the profitability of existing oil and gas production, investing in projects that deliver superior returns, capitalizing on growing natural gas and power markets, and maximizing resource value through high-impact technologies. ${ }^{109}$

ExxonMobil then disclosed planned-for shifts in geographic sourcing of oil and natural gas, as well as different types of opportunities from which it expected oil and gas volumes would be produced. ${ }^{10}$

Still, ExxonMobil did not disclose its entire upstream business strategy in its annual report. For example, it did not display its road-map for how it planned to capture the highest quality exploration opportunities, or maximize the profitability from existing oil and gas production. Thus, ExxonMobil's discussion of strategy, while more substantial than Wal-Mart's, still only highlights certain selected aspects of ExxonMobil's strategy.

In sum, my findings show that while some firms indeed provide extensive disclosure about their strategies, they do not provide the level of comprehensive disclosure that one finds in other, regulated portions of firm reports. Moreover, because such disclosures are not regularized, there is a varied level of disclosure from firm to firm.

My findings are consistent with the results of a broader study conducted by Professors Hung-Yuan (Richard) Lu and Jennifer Wu Tucker. Professors Lu and Tucker studied whether S\&P 500 firms disclosed information about their strategies as part of their fiscal year 2005 earnings announcements. ${ }^{111}$ They found that half of the studied firms did provide disclosure about

\footnotetext{
107 Wal-Mart includes similar disclosure for its other operating segments. See id. at 8, 10.

108 See Fortune 500, supra note 105.

109 Exxon Mobil Corp., Annual Report (Form 10-K), at 43 (Feb. 24, 2012), available at http:/www.sec.gov/Archives/edgar/data/34088/000119312512078102/d257530d10k.htm.

110 Id. ExxonMobil separately discussed aspects of its downstream and chemical segments' strategies in its annual report. Id. at 43-44.

111 Hung-Yuan (Richard) Lu \& Jennifer Wu Tucker, Non-Earnings Corporate Guidance, FIN. MGMT. (forthcoming) (manuscript at 4-5), available at http://ssrn.com/abstract=1415390. Professors Lu and Tucker looked at annual earnings announcements for fiscal year 2005 because
} 
their strategies, while half did not. ${ }^{12}$ Thus, they, too, found that there is no predominant practice of disclosing strategy, despite the fact that some firms choose to do so. ${ }^{113}$ Their research also supports the conclusion from my study that strategic disclosures are varied from firm to firm. ${ }^{114}$

Where a firm does choose to disclose some aspect of its strategy, those forward-looking statements generally do not subject that firm or its managers to liability. That is because such statements are protected under a safe harbor from securities laws' anti-fraud liability, so long as they are accompanied by meaningful cautionary language. ${ }^{115}$

Nevertheless, a firm may have a duty to update such statements. In particular, some courts have held managers liable for making fraudulent forward-looking statements where they failed to update previously released forward-looking information. ${ }^{116}$

For example, the Second Circuit Court of Appeal's decision in In re Time Warner ${ }^{117}$ is widely viewed as standing for the proposition that companies

that period pre-dated the CFA Institute's call for firms to replace earnings guidance with nonearnings guidance. Id. at 5 .

112 Id.

113 Their study also revealed that firms only disclose strategies for the forthcoming year. $I d$. at 17. Thus they found that firms do not disclose their longer-term strategies, which coincide with the horizon of firms' objectives.

114 Id. at $15-16$ (explaining the different codes for strategic plan disclosure based on what strategy was disclosed).

115 See 17 C.F.R. $\S 240.3 \mathrm{~b}-6$ (2013); Id. $\S 230.175$ (providing reporting companies with a safe harbor from anti-fraud liability for a "forward looking statement," defined to include financial projections, statements of management's plans and objectives for the future, and statements of future economic performance); Safe Harbor Rule for Projections, Exchange Act Release No. 15,944 [1979 Transfer Binder] Fed. Sec. L. Rep. (CCH) ๆ 82,117, at 81,938 (June 25, 1979). The Private Securities Litigation Reform Act extended the safe harbor that had originally been created by the SEC so that it applies not only to forward-looking statements in SEC reports, but to all such statements, so long as they are accompanied by proper cautionary language. Private Securities Litigation Reform Act, 15 U.S.C. \$77z-2 (2012); 15 U.S.C. \$78u- $\$$ (2012); see also Ripken, supra note 91 , at 944 . If meaningful cautionary language accompanies forward-looking statements, investors are not reasonable to rely on such information, thus defeating the reliance element of an anti-fraud claim under securities law. Ripkin, supra note 91, at 942-43.

116 See, e.g., Weiner v. Quaker Oats Co., 129 F.3d 310, 316 (3d Cir. 1997); In re Time Warner Inc. Sec. Litig., 9 F.3d 259 (2d Cir. 1993); Backman v. Polaroid Corp., 910 F.2d 10, 16-17 (1st Cir. 1990); see also Ann Morales Olazábal, False Forward-Looking Statements and the PSLRA's Safe Harbor, 86 IND. L.J. 595, 596 (2011) (stating that despite the PSLRA's safe harbor, "plaintiffs in securities fraud class actions ... routinely allege that issuers have made deliberately false projections and predictions."). According to Prof. Olazábal, this is largely due to the fact that some courts still hold managers accountable for fraudulent forward-looking statements. Id. at 605-08.

117 In re Time Warner Inc. Sec. Litig., 9 F.3d 259, 267 (2d Cir. 1993). 
must update forward-looking information. ${ }^{18}$ In In re Time Warner, Time Warner disclosed to its stockholders its plan to seek a strategic partner to contribute capital to the then over-leveraged company. ${ }^{119}$ However, Time Warner ultimately abandoned its search for a strategic partner and decided to conduct a stock offering instead, without notifying its stockholders of this possible plan. ${ }^{120}$ Stockholders sued on the basis that Time Warner's statements about its plan to pursue a strategic partnership and its omission of information about the possibility of a stock offering were misleading. ${ }^{121}$ The Second Circuit held that "a duty to update opinions and projections may arise if the original opinions or projections have become misleading as the result of intervening events."122 On that basis, Time Warner had a duty to update statements about how it planned to raise capital once it seriously began considering a stock offering as an alternative to a strategic partnership to achieve that goal. ${ }^{123}$ However, the court found that Time Warner's statements about its pursuit of a strategic partnership were not definite enough to necessitate updating once it became clear that Time Warner was having trouble locating a strategic partner. ${ }^{124}$

Similar logic would likely cause courts to extend the duty to update forward-looking information to strategic plan disclosures. That is because strategic plans are, in essence, management's plans for future operations. There would seem to be an especially significant risk of a court imposing such a duty on a firm where it disclosed some, but not all, of the strategies that it was considering, much like how the Second Circuit in In re Time Warner imposed a duty on Time Warner to disclose all of its alternative plans to raise capital. Moreover, as suggested by the court in In re Time Warner, the risk of a court imposing such a duty on a firm would likely increase with the level of detail a firm provided about its strategic plan.

\footnotetext{
118 See, e.g., Dale Arthur Oesterle, The Inexorable March Toward a Continuous Requirement for Publicly Traded Corporations: "Are We There Yet?" 20 CARDOZO L. ReV. 135, 155 (1998) ("Thus, the Second Circuit found that a public announcement of a specific plan could trigger a duty to update when consideration of an alternative plan, pursuing the same goal but in a materially different way, grew serious.").

119 In re Time Warner, 9 F.3d at 259.

$120 \quad I d$. at 262.

$121 \quad$ Id.

$122 I$ Id. at 267 (citing In re Gulf Oil/Cities Serv. Tender Offer Litig., 725 F. Supp. 712, 745-49 (S.D.N.Y. 1989)).

123 In re Time Warner, 9 F.3d at 259 n.4. For a discussion questioning whether the relevant statements at issue in In re Time Warner were historical statements or forward-looking statements, see Gregory S. Porter, What Did You Know and When Did You Know It?: Public Company Disclosure and the Mythical Duties to Correct and Update, 68 FORDHAM L. REV. 2199, $2216(2000)$
}

$124 \quad$ In re Time Warner, 9 F.3d at 267. 
Despite the risk of possibly having a duty to update, as I discussed above, many firms do voluntarily disclose their strategies, or at least aspects of their strategies.

There are a number of reasons why a firm might choose to make such disclosure despite the risk of liability. For one, while it does not require firms to disclose their strategies, the SEC expressly encourages firms to provide such additional disclosure in their reports. ${ }^{125}$ For example, in its 2003 Release discussing MD\&A, the SEC stated that it "encourage[s] companies to discuss prospective matters and include forward-looking information in circumstances where that information may not be required, but will provide useful material information for investors that promotes understanding. "126

Moreover, even though some courts have imposed a duty on managers to update soft information to prevent it from becoming misleading, ${ }^{127}$ others have found no such duty to update. ${ }^{128}$ Those decisions reinforce the notion that strategy is a private matter, even where a firm chooses at one point to disclose some aspect of its strategy.

In addition, particular firms, or firms in a particular industry, might gain more from disclosing their strategies than they lose by maintaining the secrecy of those plans. ${ }^{129}$ For example, in an industry with high barriers to entry for new competitors and difficult-to-emulate strategies, firms might view the advantages stemming from a culture of disclosure (for example, to cultivate goodwill with customers and investors) as outweighing any disadvantages. ${ }^{130}$

125 See, e.g., Securities and Exchange Act of 1934, § 10(b), 15 U.S.C. $\$ 78 \mathrm{j}(\mathrm{b})(2012)$; see also Hiler, supra note 93 , at 1120-23 (tracing through the various rules and releases reflecting the change in the SEC's position on the disclosure of projections).

126 Commission Guidance Regarding Management's Discussion and Analysis of Financial Condition and Results of Operations, Release Nos. 33-8350, 34-48960, 9 (Dec. 19, 2003) [hereinafter 2003 SEC Release].

127 See supra notes 116-24 and accompanying text.

128 See, e.g., Stransky v. Cummins Engine Co., Inc., 51 F.3d 1329, 1333 (7th Cir. 1995); see also Stephen E. Bochner \& Samir Bukhari, The Duty to Update and Disclosure Reform: The Impact of Regulation FD and Current Disclosure Initiatives, 7 STAN. J.L. Bus. \& FN. 225, 235 (2002); Carl W. Schneider \& Jay A. Dubow, Forward-Looking Information-Navigating in the Safe Harbor, 51 Bus. LAw. 1071, 1077 n.36 (1996).

129 See Lu \& Tucker, supra note 111, at 11-14, 28-29 (finding that disclosing strategy reduces informational asymmetry between managers and shareholders, which can, in turn, lead to an improvement in stock liquidity).

130 See also id. at 6-7, 28-29 (finding that "shakeout" firms (i.e., firms between the mature and decline stages) tend to provide more strategic disclosure than growth firms). This raises the question whether managers of a firm in a particular industry would provide such disclosure acting alone, or only in coordination with other firms in that industry, who provide similar disclosure. On that point, see Dallas, supra note 66, at 301-02 (using the prisoner's dilemma analogy to explain why managers do not coordinate to act in the long-term best interest of their respective firms and why firms' managers have not privately coordinated to provide relevant long-term disclosures to investors). 
However, this would likely only apply to specific firms or industries, and not to firms more generally. Thus the general rule remains-that public firms need not disclose their strategies unless they choose to.

\section{Mandated Disclosure of Risk}

In contrast to the lack of mandates as to the disclosure of strategy, securities mandates require public firms to provide a healthy dose of information about risk. ${ }^{131}$ That disclosure focuses on events and circumstances that might cause a firm's financial results to be lower than its historic results. In that way, investors receive some words of caution about over-relying on reported historic results in light of potential future events that might cause results to decrease.

The rest of this Subsection discusses the three central rules that require public firms to provide information about risk: first, the rule requiring information about forward-looking trends and uncertainties included in Management's Discussion and Analysis of Financial Condition and Results of Operations; second, the rule requiring information about market risk and market risksensitive instruments; and third, the rule requiring information about risk factors.

\section{a. Management's Discussion and Analysis}

The most obvious example of mandated, forwarding-looking disclosure about risk is found in Management's Discussion and Analysis of Financial Condition and Results of Operations, or MD\&A, which must be included in every public firm's quarterly and annual report. ${ }^{132} \mathrm{MD} \& \mathrm{~A}$ primarily calls for a narrative discussion by management of a firm's historic financial statements that is intended to enable investors to see the firm through management's eyes. ${ }^{133}$ It also provides investors with context behind historic financial statements. $^{134}$

\footnotetext{
131 See Roger J. Dennis, Mandatory Disclosure Theory and Management Projections: A Law and Economics Perspective, $46 \mathrm{MD}$. L. REV. 1197,1199 (1987) (noting that the SEC changed its attitude toward soft information because it "recognized that forward-looking data was perhaps the most useful type of information for investors.").

132 See U.S. SEC. \& EXCh. COMM'N, FORM 10-K: ANNUAL RePORT PURSUANT TO SECTION 13 OR 15(D) OF THE SECURITIES ACT OF 1933, at 9, http://www.sec.gov/about/forms/form10-k.pdf (last visited Sept. 6, 2013) [hereinafter Form 10-K]; U.S. SEC. \& EXCH. COMM'N, FORM 10-Q, at 5, http://www.sec.gov/about/forms/form10-q.pdf (last visited Sept. 6, 2013) [hereinafter Form $10-\mathrm{Q}]$. This information is also incorporated by reference from these periodic reports into public companies' securities offerings. See, e.g., U.S. SEC. \& EXCH. COMM'N, FORM S-3: REGISTRATION STATEMENT UNDER THE SECURITIES ACT OF 1933, at 11-12, http://www.sec.gov/ about/forms/forms-3.pdf (last visited Sept. 6, 2013) [hereinafter Form S-3].
}

133 According to the SEC, 
While MD\&A is thus primarily a discussion of historic information, it does call for some forward-looking information. ${ }^{135}$ In fact, according to the SEC, one of the purposes "of MD\&A is to provide information about the quality of, and potential variability of, a company's earnings and cash flow, so that investors can ascertain the likelihood that past performance is indicative of future performance." $" 136$

The type of forward-looking information that must be disclosed in MD\&A is information about known material trends and uncertainties that are reasonably likely to have a material effect on the firm's financial condition or operating performance. ${ }^{137}$ In other words, if managers believe that it is reasonably likely that a trend or future event or circumstance will cause future reported results or financial condition to materially vary from reported results, they must disclose that.

This disclosure is intended to enable investors to determine whether past reported performance is truly indicative of future performance. ${ }^{138}$ That is important because investors calculate a firm's value by looking at its expected future cash flows. ${ }^{139}$ Yet disclosure mandates focus primarily on historic re-

[t]he MD\&A requirements are intended to satisfy three principal objectives: to provide a narrative explanation of a company's financial statements that enables investors to see the company through the eyes of management; and to enhance the overall financial disclosure and provide the context within which financial information should be analyzed; and

to provide information about the quality of, and potential variability of, a company's earnings and cash flow, so that investors can ascertain the likelihood that past performance is indicative of future performance.

2003 SEC Release, supra note 126, at 2.

$134 \quad I d$.

135 Id.

136 Id. at 13 (emphasis added); see also id. at 7.

Throughout MD\&A, including in an introduction or overview, discussion and analysis of financial condition and operating performance includes both past and prospective matters. In addressing prospective financial condition and operating performance, there are circumstances, particularly regarding known material trends and uncertainties, where forward-looking information is required to be disclosed. We also encourage companies to discuss prospective matters and include forward-looking information in circumstances where that information may not be required, but will provide useful material information for investors that promotes understanding.

Id.

13717 C.F.R. \& 229.303(a), Instruction 3 (2013); see also 2003 SEC Release, supra note 126, at 9.

1382003 SEC Release, supra note 126, at 9.

139 Tim Koller ET AL., VALUATION: MEASURING AND MANAGING THE VALUE OF COMPANIES 56 (4th ed. 2005); see also 2003 SEC Release, supra note 126, at 11.

One of the principal objectives of MD\&A is to provide information about the quality and potential variability of a company's earnings and cash flow, so 
sults. As a result, managers have a duty to tell investors when they know that historic results are not indicative of expected future performance.

Still, MD\&A only calls for information about known trends and uncertainties. In other words, the information MD\&A calls for is not about prospective strategies, but about specific changed events and circumstances that managers are aware of and that are reasonably likely to occur. MD\&A also does not call for forward-looking information that is speculative or uncertain, such as revenues or cash flows estimated to be generated from implementation of the selected strategic plan.

Moreover, despite the fact that MD\&A could be interpreted as calling for the disclosure of both up-side risks (i.e., opportunities that could lead to higher results than expected) and down-side risks (i.e., threats that could lead to lower results than expected), SEC guidance has only focused on the disclosure of down-side risks. For example, in its 1989 interpretive release pertaining to MD\&A, the SEC listed numerous examples of events that would require disclosure, all involving down-side risks. ${ }^{140}$ The absence of any SEC efforts to force firms to provide information about reasonably likely opportunities that could lead to future gains as part of MD\&A suggests that MD\&A's focus is intended to be on forward-looking down-side risks. ${ }^{141}$

Further, firms are understandably cautious in making statements about the future in MD\&A because of the possible risk of liability for forward-looking statements. ${ }^{142}$ That risk exists not only where a firm makes affirmative misstatements about the future, but also where a firm omits material information

\footnotetext{
that readers can ascertain the likelihood that past performance is indicative of future performance. Ascertaining this indicative value depends to a significant degree on the quality of disclosure about the facts and circumstances surrounding known material trends and uncertainties in MD\&A.
}

Id.; see also Raghuram G. RAJAN, Has Financial Development Made the World RISKiER? 313, 349 (Fed. Reserve Bank of Kansas City symposium paper) (Jackson Hole, Wyoming, 2005), available at http://www.KansasCityfed.org/publicat/sympos/2005/pdf/rajan2005.pdf (arguing that past performance in most cases is not a good predictor of future performance).

140 See Management's Discussion and Analysis of Financial Condition and Results of Operations; Certain Investment Company Disclosures, Exchange Act Release No. 34-26831, 43 SEC Docket 1330, 1333 (May 18, 1989) (Giving as examples of known material trends and uncertainties that must be disclosed "[a] reduction in the registrant's product prices; erosion in the registrant's market share; changes in insurance coverage; or the likely non-renewal of a material contract.").

141 Even if MD\&A did require the disclosure of up-side opportunities in addition to down-side threats, it is hard to see how investors would be "damaged" by a firm's failure to disclose a reasonably likely opportunity that might lead to gains.

142 See supra notes 116-24 and accompanying text. While the safe harbor from liability for forward-looking statements was designed to give firms the freedom to make projections and discuss the future up-side potential of their firm's operations, it has also been applied to forwardlooking statements about down-side risk. Ripken, supra note 91, at 94445. 
about the future, such as about future trends and uncertainties. ${ }^{143}$ Undoubtedly for this reason, firms tend to over-disclose down-side trends and uncertainties in MD\&A. ${ }^{144}$ As a result, investors cannot distinguish those disclosed risks that are probable from those that are merely possible, or those that are material from those that are immaterial. ${ }^{145}$ This is true despite words of caution from the SEC to avoid making overly complex and lengthy disclosures in MD\&A. ${ }^{146}$

\section{b. $\quad$ Market Risk and Market-Sensitive Instruments}

The SEC also requires disclosure with respect to market risk. Market risk is the risk that assets whose prices are determined by market-wide factors-such as commodity prices or interest rates-will fluctuate. ${ }^{147}$

Pursuant to Item 305 of Regulation S-K, ${ }^{148}$ every reporting company must disclose in its periodic reports quantitative and qualitative information about its market risk, as well as its exposure to market risk-sensitive instruments. ${ }^{149}$ That disclosure includes, for each of those instruments, whether that

143 See 17 C.F.R. $\S 240.10 b-5$ (2013) (including, for purposes of anti-fraud liability under the Securities Exchange Act of 1934, an omission of "a material fact necessary in order to make the statements made, in light of the circumstances under which they were made, not misleading").

144 See 2003 SEC Release, supra note 126, at 6 (noting that many companies' MD\&As "may have become unnecessarily lengthy, difficult to understand and confusing"); Donald C. Langevoort, Managing the "Expectation Gap" in Investor Protection: The SEC and the Post-Enron Reform Agenda, 48 VILL. L. REV. 1139, 1155-56 (2003) (arguing that disclosure of possible risks tends to lead to boilerplate disclosure). But see John L. Campbell et al., The Information Content of Mandatory Risk Factor Disclosures in Corporate Filings, REV. ACCT. STUD. (forthcoming 2013) (manuscript at 3), available at http://papers.ssrn.com/sol3/papers.cfm? abstract_id=1694279 (noting that the "evidence suggests that - contrary to critics" assertions risk factor disclosures are not boilerplate, but instead meaningfully reflect the risks a firm faces").

145 See Langevoort, supra note 144, at 1155-56 (arguing in favor of disclosure that not only identifies possible risks, but that also discusses their probability and magnitude).

146 See, e.g., 2003 SEC Release, supra note 126, at 6-7.

147 See Zachary J. Gubler, The Financial Innovation Process: Theory and Application, 36 DEL. J. CORP. L. 55, 62 (2011).

148 Regulation S-K creates a system of standardized disclosure for non-financial information in Exchange Act reports, registration statements under the Securities Act, and other documents filed with the SEC. See 17 C.F.R. $\S 229.10$ (2013).

149 See 17 C.F.R. $\S 229.305$ (2013) [hereinafter Regulation S-K, Item 305]; see also id. $\S$ 229.305(a), Instruction 2. This rule has been the subject of much criticism. See Martin H. Dozier, Note, Barings's Ghost: Item 305 in SEC Regulation S-K and "Market Risk" Disclosures of Financial Derivatives, 34 GA. L. REV. 1417, 1447-51 (2000) (describing hearings before the Senate Banking Securities Subcommittee in which numerous witnesses, including the SEC's chief economist, questioned whether Item 305 would benefit investors). Its passage also accompanied new accounting rules dictating how to account for such derivatives. $I d$. at 1451 . This information on market risk is also incorporated by reference into public companies' securities offerings. See, e.g., Form S-3, supra note 132. 
instrument could result in a reasonably possible effect on the firm due to market changes. ${ }^{150}$

This disclosure heightens the risk-based disclosure called for in MD\&A because MD\&A already calls for firms to disclose information about risks that are reasonably likely to materially affect the firm. ${ }^{151}$ That includes information about market risk. ${ }^{152}$ Item 305 , in contrast, uses a lower threshold for disclosure-specifically, it calls for disclosure based on the reasonably possible standard. That means that firms must disclose not only market risk and market risk-sensitive instruments that are reasonably likely to materially affect them, but also such risk and instruments that will have a reasonably possible material impact on them.

This disclosure reveals more information about market risk, and how it is managed, than it does about other kinds of risks. This specialized treatment given to market risk and market risk-sensitive instruments has been criticized by some on the basis that it might mislead investors. ${ }^{153}$ Those critics argue that heightening disclosure about market risk compared to other risks suggests that this risk is of a greater concern than other risks. ${ }^{154}$ That, indirectly, might imply that other risks are less important. ${ }^{155}$ Yet other risks, such as operational risks associated with poor business decisions, would seem to pose as great of a risk to a firm as market risk. ${ }^{156}$

Other critics of Item 305 have argued that the rule calls for disclosure about a firm's proprietary trading strategies. ${ }^{157}$ By disclosing information about what market risk-sensitive instruments a firm has entered into, a firm allows its competitors to see the ways in which the firm manages its market risk. This challenge highlights the interrelatedness between strategy and risk, for the selection and implementation of a firm's strategy are what give rise to risks that need to be managed. It also flags the concern that due to that interrelatedness, rules pertaining to down-side risk might reveal something about a firm's strategy for wealth-creation. The fact that the disclosure of risk might compromise the confidentiality of a firm's strategy as to trading in market risk-sensitive in-

\footnotetext{
$150 \quad$ Regulation S-K, Item 305, supra note 149.

151 See supra note 137 and accompanying text.

152 Dozier, supra note 149 , at 1454.

153 See, e.g., id. at 1461.

154 See, e.g., id. at 1462.

$155 I d$. at 1462-64. Other critiques focus on the fact that this rule leads to information overload. $I d$. at 1464 .

156 See id. at 1463 (citing to Derivatives Disclosure and Accounting: Hearings Before the Subcomm. on Sec. of the Senate Comm. on Banking, Housing, and Urban Affairs, 105th Cong. 9 (1997) (opening statement of Sen. Lauch Faircloth) ("Empirically, the risk of loss resulting from a poor business decision can far outweigh any potential losses incurred through the use of derivatives.")).
}

157 See id. at $1467-69$. 
struments might explain why Congress and the SEC have increasingly required the disclosure not of risk itself, but of processes to manage risk. ${ }^{158}$

\section{c. Risk Factors}

Additionally, every firm must include in its periodic reports filed with the SEC a statement of what it views as its primary "risk factors"factors that make an investment in the firm's securities risky or speculative. ${ }^{159}$ SEC guidance once again suggests that this rule merely calls for the disclosure of down-side risk. For example, in a Staff Legal Bulletin issued by the SEC in 1999 explaining how to draft risk factors in plain English, the SEC gave several examples of risk factors both before and after they had been drafted in plain English. ${ }^{160}$ Each of the exemplified risk factors involved a down-side risk. ${ }^{161}$ Consistently, in the same study mentioned above, only a handful of the companies in my sample discussed any up-side risks-or opportunities-in their discussion of risk factors. ${ }^{162}$

Other SEC rules, forms, and guidance also reinforce the conclusion that risk-factors for purposes of SEC disclosures cover only down-side risk. For example, Regulation A's offering rules call for the disclosure of risk factors, and describe those as "factors which constitute the greatest threat that the investment will be lost in whole or in part, or not provide an adequate return." 163

\footnotetext{
158 See discussion infra Section III.B.

159 See 17 C.F.R. $\$ 229.503$ (c) (2013); Form 10-K, supra note 132, at 8 (calling for disclosure of risk factors from Item 503(c)); Form 10-Q, supra note 132, at 6 (calling for disclosure of any changes to the risk factors disclosed in the issuer's latest annual report on Form 10-K); see also 17 C.F.R. $\S 230.421$ (d) (2013) (mandating disclosure of risk factors in securities offerings).

160 See SEC Staff Legal Bulletin No. 7: "Plain English Disclosure"(June 7, 1999), available at http://www.sec.gov/interps/legal/cf slb7a.htm.

161 See id.

162 In the study, I found that approximately $4 \%$ of the companies discussed positive risks (i.e., ones that represent opportunities that might generate gains) in their "risk factors," whereas roughly $96 \%$ of the companies did not discuss any positive risks in their "risk factors." For more information about the study, see supra note 94 and accompanying text.

163 See U.S. SeC. \& Exch. COMm'N, Regulation A OFFERING STATEMENT Under the SECURITIES ACT OF 1933, FORM 1-A, 7, available at http://www.sec.gov/about/forms/forml-a.pdf (last visited Sept. 4, 2013); see also Catherine T. Dixon, SEC Disclosure and Corporate Governance: Financial Reporting Challenges for 2011, HARVARD LAW SCHOOL CORPORATE GOVERNANCE BLOG (Mar. 15, 2011, 8:14 AM), http://blogs.law.harvard.edu/corpgov/2011/ 03/15/sec-disclosure-and-corporate-governance-financial-reporting-challenges-for-2011/.
}

The overarching theme of this guidance [referring to SEC guidance in 2010 and 2011]-whether formally outlined in binding SEC pronouncements or non-binding Staff interpretations, or informally expressed by Staff members in speeches-is the importance of providing 'early-warning' disclosures of material risks and uncertainties that, if realized, could have a material adverse effect on a particular company's liquidity, capital resources or operating results. 
By focusing only on threats that will lead to losses, Regulation A's offering rules clearly call only for disclosure of down-side risk, but not opportunities. This once again shows the focus of securities mandates on disclosure of downside risk rather than up-side wealth-creating strategies.

\section{Rationale for Disparate Risk and Strategy Disclosures}

As the above discussion shows, firms need to disclose a host of information about the material risks that they and their investors face, with a focus on risks that might cause future results to differ from historic results. In contrast, they need not disclose anything about their strategies other than as the result of a potential duty to update a previously disclosed strategy.

There are a number of likely reasons why securities mandates only require disclosure of risks and not strategies.

First, firms might not have to disclose their strategies because such disclosure could ruin their competitive advantage. ${ }^{164}$ For example, consider a firm like Apple, whose strategies are shrouded in secrecy. ${ }^{165}$ It is easy to imagine how Apple's strategy might be impaired if it were required to disclose what new products it planned to develop, for that firm's competitors might be able to develop a similar new product first, gaining an advantage through being the first mover. ${ }^{166}$ Thus, as Professor Kitch observed over a decade ago, "information is power, including the power to compete effectively. In the hands of competitors and others with interests adverse to the issuer, information relevant to accuracy enhancement can be used to harm the issuer." 167

This same rationale explains why state trade secret law protects the confidentiality of firms' strategies. In particular, under the Uniform Trade Secret Act in effect in most states, ${ }^{168}$ a firm's strategy is a trade secret so long as

\section{Id. (emphasis added).}

164 See DAVID, supra note 84, at 302. This is especially true where a company's strategy involves a potential merger. See Bershad v. Curtiss-Wright Corp., 535 A.2d 840, 847 n.5 (Del. 1987) ("[T]he effect of premature disclosure of merger discussions may be substantial. The probability of completing a merger benefiting all shareholders may well hinge on secrecy during the negotiation process."). But even without a merger, a firm often retains an advantage due to the secrecy of its strategy.

165 See Lashinsky, supra note 4, at 131 (describing the secrecy surrounding even the time period covered by Apple's strategic plan).

166 See id. at 127 (quoting Tom Cook as saying, in response to a question by a Wall Street analyst about how far out Apple plans, "Well, that is a part of the magic of Apple. And I don't want to let anybody know our magic because I don't want anybody copying it."').

167 Edmund W. Kitch, The Theory and Practice of Securities Disclosure, 61 BROOK. L. REV. 763,772 (1995).

168 See RESTATEMENT (THIRD) OF UNFAIR COMPETITION $\$ 39$ (1995) (listing jurisdictions that have adopted the Uniform Trade Secret Act). 
the firm takes reasonable steps to maintain its secrecy. ${ }^{169}$ This rule "encourage[s] investment in research by providing an opportunity to capture the returns from successful innovations." 170 While state trade secret law would not preempt an inconsistent federal mandate on disclosure, the policies behind protecting strategic plans as trade secrets help explain why neither Congress nor the SEC mandate their disclosure. ${ }^{171}$

Again, for some companies, the benefits of disclosing their strategies, or at least some aspects of their strategies, outweigh the costs. ${ }^{172}$ Yet the fact that that is true for only some companies militates against adopting a broadly applicable rule that would require all public companies to disclose their strategies.

In addition, the securities mandates may not require firms to disclose their strategies because managers are thought to want to volunteer information that would paint a rosy picture of their firms, such as positive information about their firms' strategies. ${ }^{173}$ In contrast, managers are thought to not want to disclose events that might lead to losses, for that could lead to a lower firm value and, in turn, a lower stock price. ${ }^{174}$ Thus, disclosure mandates are necessary only to balance out the optimistic account that managers are thought to have a tendency to supply.

While it may be true that managers prefer to disclose the affirmative value-creating aspects of their business rather than the potentially negative, value-decreasing aspects, as I discussed in Subsection 1 above, most firms either do not disclose their strategies, or if they do so, only disclose some aspects of their strategies within other disclosure. Such incomplete, tucked-away disclosure hardly suggests that managers are trying to highlight their firms' plans to create wealth.

In conclusion, the absence of a duty on firms to disclose their strategies is justified on the basis that it protects the competiveness of those firms. Still, investors would undoubtedly better understand disclosed risks if they knew the strategic choices that led to them. That is true even though the information that

\footnotetext{
169

Id. at cmt. f; see also Frank J. Cavico, Business Plans and Strategies as Legally Protected Trade Secrets: Florida and National Perspectives, 9 U. MiAMI Bus. L. REV. 1, 17-19 (2001).

170 Restatement (THIRD) OF UNFAIR COMPETITION $\$ 39 \mathrm{cmt}$. a (1995).

171 See supra notes 91-102 and accompanying text.

172 See supra notes 125-130 and accompanying text.

173 See Donald C. Langevoort, Organized Illusions: A Behavioral Theory of Why Corporations Mislead Stock Market Investors (and Cause other Social Harms), 146 U. PA. L. REv. 101, 157 (1997); Ripken, supra note 16, at 170 ("Executives are likely to provide disclosure that is habitually overoptimistic and self-serving, which can be misleading to the public.").

174 See S. P. Kothari et al., Do Managers Withhold Bad News?, 17 J. OF ACCT. RES. 241, 24244 (2009); Ewa Sletten, The Effect of Stock Price on Discretionary Disclosure, 17 REV. OF ACCT. STUD. 96 (2012). But see Kothari, supra, at 244 (noting that "[m]anagers' tendency to withhold bad news is attenuated for firms with high litigation risk").
} 
firms must provide about risks is limited, and based on the estimated likelihood of the risk. ${ }^{175}$ Such imbalanced disclosure, too, might justify a disclosure regime in which current strategic management processes, rather than forwardlooking and confidential strategies, are required to be disclosed.

\section{B. Mandated Disclosure as to Management Processes}

The next section of this discussion reviews legal mandates as to risk and strategic management processes. It begins in Subsection 1 with a discussion of mandates - or more accurately, the lack of mandates-relating to strategic management. Next, Subsection 2 reviews mandates relating to risk management.

\section{1. (Non)-Mandated Disclosure of Strategic Management Process}

Much like with strategy, there are no securities mandates that require public firms to disclose any aspect of their strategic management processes. For example, while the SEC requires disclosure as to the board's role in overseeing the management of risk, ${ }^{176}$ it does not require disclosure as to the board's role in overseeing the management of strategy.

Still, according to several SEC no-action letters, firms may not exclude from their proxy statements shareholder proposals calling for the disclosure of the board's role in the strategic planning process. ${ }^{178}$ In those letters, the SEC expressed the view that the board's participation in the development and implementation of the company's long-term strategic plan was beyond its ordinary business operations. ${ }^{179}$ Thus, those companies could not exclude the proposals on that basis. ${ }^{180}$

Those no-action letters do not address whether the firms at which they were submitted could have excluded such proposals on the basis that the information they called for was confidential. Yet, the fact that none of the firms re-

\footnotetext{
175 See supra notes 137, 150 and accompanying text. Still, firms do not have to provide a particular estimated probability of any risk occurring, or estimate its likely magnitude. See supra note 145 and accompanying text.

176 See infra note 223 and accompanying text.

177 See Ameren Corp., SEC No-Action Letter, 2002 WL 287871 (Jan. 24, 2002) (noting that none of the cited-to SEC rules and no-action letters requires disclosure of information about the board's role in the strategic planning process) [hereinafter Ameren Corp. No-Action Letter].

178 See, e.g., id.; Duke Energy Corp., SEC No-Action Letter, 2002 WL 253889 (Mar. 1, 2002) [hereinafter Duke Energy Corp. No-Action Letter].

179 See, e.g., Ameren Corp. No-Action Letter, supra note 177; Duke Energy Corp. No Action Letter, supra note 178.

180 See, e.g., Ameren Corp. No-Action Letter, supra note 177; Duke Energy Corp. No- Action Letter, supra note 178.
} 
ceiving one of these proposals raised that challenge in its request for no-action relief suggests that they did not view such information as confidential. In any event, the ad hoc nature of the disclosure these firms had to make in response to specific shareholder requests contrasts with the systematic and mandatory nature of the equivalent disclosure as to the board's role in overseeing the management of risk, as is discussed below.

It is possible that there is no universal securities mandate requiring firms to regularly provide information about their strategic management processes because they already provide such information voluntarily. However, the evidence belies this conclusion. In particular, in the same study mentioned above, I found that by and large, public firms do not disclose anything about their processes to formulate strategy apart from possibly identifying the executive officer in charge of strategic planning. ${ }^{181}$ And even as to that disclosure, firms generally only identify the person in charge of strategic planning if that person is a "named executive officer." 182 In other words, firms typically do not disclose who spearheads their strategic planning effort unless that is a person for whom disclosure must otherwise be provided under securities laws.

\section{Mandated Disclosure of Risk Management Process}

In contrast to the absence of mandates as to strategic management, there is an increasing number of mandates as to risk management. In fact, the number of mandates as to risk management has blossomed following the turnof-the-century accounting scandals and credit crisis, which revealed deficiencies in risk management processes and the failure of the existing disclosure scheme to prevent them. Thus, there has been a shift in legislative and regulatory focus toward more disclosure about processes to manage those risks. ${ }^{183}$

The theory behind this kind of disclosure is to allow investors to make a more informed judgment about a firm's value and governance based not on

\footnotetext{
181 In the study, I found that roughly $82 \%$ of the companies disclosed either nothing or very little about their processes to set strategy, whereas approximately $18 \%$ of the companies discussed significant aspects of those processes. For purposes of the study, I limited my review to disclosure of the planning processes, for it would seem that if a company discloses anything about its strategic management process, it would most likely disclose the process through which it formulated its strategy rather than the other, less defined stages.

182 In the study, I found that just over half of the reporting companies identified an officer as being in charge of strategic planning, whereas just under half of the companies did not identify an officer in charge of strategic planning.

183 See Mary L. Schapiro, Chairman, U.S. Sec. \& Exch. Comm'n, Address to the Counsel of Institutional Investors (Apr. 6, 2009) ("The Commission will be considering whether greater disclosure is needed about how a company - and the company's board in particular - manages risks, both generally and in the context of setting compensation.").
} 
disclosure of risk itself, but on processes to manage risk. ${ }^{184}$ In that way, investors can make a more informed judgment about a firm's risk-taking in light of the perceived effectiveness of its risk management processes. In addition, investors can hold management accountable for actually engaging in disclosed risk management processes.

Each of the two crises revealing deficiencies in risk management practices, along with the associated risk management reform, is discussed next.

\section{a. Enron and Risk Management Requirements}

Enron's story is widely known. Starting in the 1980s, Enron capitalized on the deregulation of energy markets to become the leading U.S. natural gas company. ${ }^{185}$ However, as its competitive advantage started to slip and competitors such as El Paso and Dynegy started to enter the newly deregulated market, Enron was forced to decide whether to be satisfied with lower profit margins or to try to replicate its success in other sectors. ${ }^{186}$ It chose the latter approach, diversifying into the energy trading markets as well as water, power generation, coal, paper and forest products, telecommunications, retail electricity, and metals. ${ }^{184}$ However, Enron was unable to apply its expertise as a natural gas company to these new markets. ${ }^{188}$

As Enron started to experience significant losses from these non-core businesses, it needed to raise capital to continue implementing its expansion strategy. ${ }^{189}$ Yet any reported new debt could have decreased Enron's credit rating, which in turn could have compromised its ability to engage in energy

\footnotetext{
184 See Proxy Disclosure Enhancements, Securities Act Release No. 33-9089, Exchange Act Release No. 34-61175, 47 Fed. Reg. 68,834 (Dec. 23, 2009) [hereinafter Proxy Disclosure Enhancements] (stating that the proxy disclosure enhancements, which call for information about the board's role in risk oversight, will significantly improve the information provided by companies to their shareholders about risk).

185 John R. Kroger, Enron, Fraud, and Securities Reform: An Enron Prosecutor's Perspective, 76 U. COLO. L. REV. 57, 64 (2005).

186 Id. at 64-65.

187 Id. at 65.

188 Id. at 66.

189 See id. at $67-68$
} 
trading. ${ }^{190}$ Thus began the accounting manipulations to hide the true state of Enron's losses. ${ }^{191}$

Enron's board, along with the boards at other firms that faced similar situations, ${ }^{192}$ was lambasted for failing to detect these accounting manipulations. ${ }^{193}$ Congress reacted swiftly to these cries with the Sarbanes-Oxley Act of 2002 (SOX). ${ }^{194}$

One of the most significant (and controversial) aspects of SOX involves the rules pertaining to "internal control over financial reporting," or ICOFR. ICOFR refers to a process by which a firm ensures the reliability of its financial reporting and the preparation of financial statements for external purposes. ${ }^{195}$ In other words, a firm uses ICOFR to control its operational risks associated with the preparation of financial statements and the reporting of financial results to investors and other constituents.

The SEC adopted the Committee of Sponsoring Organizations of the Treadway Commission's (COSO) definition of ICOFR, which had previously been adopted by the American Institute of CPAs. ${ }^{196}$ Under that definition, internal controls are defined as a process intended to provide reasonable assurance regarding the firm's (1) effectiveness and efficiency of operations, (2) reliability of financial reporting, and (3) compliance with applicable laws and

190 See id. at 68; Milton D. Regan, Jr., Teaching Enron, 74 ForDHAM L. REV. 1139, 1150 (2005) (noting that "to continue grow[th] in its trading operations, Enron needed to trade without having to post collateral" which "in turn depended on its credit rating [and that] [i]ncurring additional debt could cause that rating to be downgraded."). According to Professor Regan, Enron did not want to issue additional equity either, as that would lower earnings per share, which would make it harder to hit the earnings targets that the company had indicated to stock analysts. Id.

191 See Kroger, supra note 185, at 72. Enron CFO Andrew Fastow eventually admitted to this purpose: "While CFO, I and other members of Enron's senior management fraudulently manipulated Enron's publicly reported financial results. Our purpose was to mislead investors and others about the true financial position of Enron and, consequently, to inflate artificially the price of Enron's stock and maintain fraudulently Enron's credit rating." Id. (citing Plea Agreement at Ex. A, United States v. Fastow, Cr. No. H-02-0665 (S.D. Tex. Jan. 14, 2004) (statement of defendant, dated January 4, 2004)).

192 The list of such other firms includes WorldCom, Global Crossing, Adelphia Communications and Tyco. Penelope Patsuris, The Corporate Scandal Sheet, Forbes (Aug. 26, 2002, 5:30 PM), http://www.forbes.com/2002/07/25/accountingtracker.html.

193 See, e.g., id.; Kroger, supra note 185, at 95-97.

194 Sarbanes-Oxley Act of 2002, Pub L. 107-204, 116 Stat. 745 (2002).

19517 C.F.R. $\$ 240.13 \mathrm{a}-15(\mathrm{f}),-15 \mathrm{~d}-15$ (f) (2013).

196 Management's Report on Internal Control over Financial Reporting and Certification of Disclosure in Exchange Act Periodic Reports, Securities Act Release No. 33-8238, Exchange Act Release No. 34-47986, Investment Company Act Release No. IC-26068 [2003 Transfer Binder] Fed. Sec. L. Rep. (CCH) $₫ 86,023$ (Jun. 5, 2003) [hereinafter Management's Report on Internal Control], available at $\mathrm{http} / / / \mathrm{www} . \mathrm{sec}$.gov/rules/final/33-8238.htm. 
regulations. ${ }^{197}$ However, the SEC intentionally chose to exclude (1) and (3) from its required control framework. ${ }^{198}$ The SEC likely excluded such controls because it is primarily concemed with ensuring that financial statementswhich are the primary focus of SEC-filed reports-are accurate. As a consequence, ICOFR does not cover controls designed to provide reasonable assurances about the successful implementation of a firm's strategy.

There are numerous mandates within SOX with respect to ICOFR. First, it obligates managers to annually assess and report on their firm's ICOFR. ${ }^{199}$ It also imposes greater responsibility on the CEO and CFO for ICOFR by requiring those officers to certify as to the effectiveness of such controls. ${ }^{200}$ CEOs and CFOs face potential liability if they certify to the effec-

197 CONSIDERATION OF INTERNAL CONTROL IN A FINANCIAL STATEMENT Audit: AN AMENDMENT TO STATEMENT ON AUDITING STANDARDS No. 55, Statement on Auditing Standards No. 78 (Am. Inst. of Certified Pub. Accountants 1995). That auditing standard has since been superseded by Auditing Standard No. 5, promulgated by the Public Company Accounting Oversight Board, an agency established under SOX. See AN AUDIT OF INTERNAL CONTROL OVER FINANCIAL REPORTING THAT IS INTEGRATED WITH AN AUDIT OF FnNANCLAL STATEMENTS, Auditing Standard No. 5 (Pub. Co. Accounting Oversight Bd. 2007), available at http://pcaob.org/Rules/Rules of-the Board/Auditing Standard_5.pdf. Pre-SOX, public companies were also required to put in place internal controls necessary to provide assurances as to the implementation only of authorized transactions, accountability of assets and the proper recording of transactions for accounting purposes, under the Foreign Corrupt Practices Act (FCPA). See Foreign Corrupt Practices Act of 1977, Pub. L. No. 95-213, 91 Stat. 1494, § 13(b) (codified as amended at 15 U.S.C. $\S 78 \mathrm{~m}$ ). Under the FCPA, any officer, director, employee or agent who willfully violates this provision of the FCPA may face penalties of up to $\$ 100,000$ and up to five years in jail. 15 U.S.C. $\$ 78 \mathrm{dd}-2(\mathrm{~g})(2)(2012)$.

198 See Management's Report on Internal Control, supra note 196 ("We recognize that our definition of the term 'internal control over financial reporting' reflected in the final rules encompasses the subset of internal controls addressed in the COSO Report that pertains to financial reporting objectives.").

199 See Sarbanes-Oxley Act of 2002, Pub. L. No. 107-204, $\S 404$ (a), 116 Stat. 745, 789 (codified at 15 U.S.C. $\S 7262$ ); see also Form 10-K, supra note 132, at 9-10; 17 C.F.R. $\S 229.308$ (2013); Commission Guidance Regarding Management's Report on Internal Control over Financial Reporting Under Section 13(a) or 15(d) of the Securities Exchange Act of 1934, Securities Act Release No. 33-8810, Exchange Act Release No. 34-55929, 72 Fed. Reg. 35,324, 35,324-25 (June 27, 2007) [hereinafter Commission Guidance Regarding Internal Control] ("The Interpretive Guidance is organized around two broad principles. The first principle is that management should evaluate whether it has implemented controls that adequately address the risk that a material misstatement of the financial statements would not be prevented or detected in a timely manner. . The second principle is that management's evaluation of evidence about the operation of its controls should be based on its assessment of risk.").

200 See Sarbanes-Oxley Act of 2002, Pub. L. No. 107-204, § 302, (codified at 15 U.S.C. § 7241); see also Form 10-K, supra note 132, at 11; 17 C.F.R $\S 229.601(31)$; Id. $\S 240.13 \mathrm{a}-14(\mathrm{a})$; Id. $\S 240.15 \mathrm{~d}-14(\mathrm{a}) \mathrm{v}$. 
tiveness of their firms' ICOFR where such control proves to not have been effective. ${ }^{201}$

Moreover, SOX obligates public companies to have their auditors attest to and report on management's assessment of the effectiveness of their ICOFR. ${ }^{202}$ While some commentators believe that this auditor attestation requirement significantly enhanced the reliability of internal controls, ${ }^{203}$ others view this requirement as an inefficiently costly measure. ${ }^{204}$ The inefficiencies were most profound on small companies, ${ }^{205}$ leading the SEC to permanently exempt smaller public companies from this rule. ${ }^{206}$

SOX also sought to enhance board oversight over ICOFR. It did that by charging the audit committee (rather than officers) with selecting, compensating and overseeing the auditor. ${ }^{207}$ Therefore, audit committees must not only oversee officers in the preparation of financial statements, but must also di-

201 The officer would not only face potential criminal sanctions for having violated Section 13(a) or 15(d) of the Exchange Act, but also a private action for having violated Section 10(b) of the Exchange Act and Rule 10b-5 promulgated under that act. See Certification of Disclosure in Companies' Quarterly and Annual Reports, Securities Act Release No. 824, Exchange Act Release No. 46427, Investment Company Act Release No. 25722, 67 Fed. Reg. 57, 276 (Sept. 9, 2002) [hereinafter Section 302 Release]. Issuers must also disclose quarterly any changes in their internal controls over financial reporting. See Form 10-Q, supra note 132, at 5.

202 See supra note 200.

203 See, e.g., David Henry, Not Everyone Hates SarbOx, BuSINESSWEEK (Jan. 29, 2007), http://www.businessweek.com/magazine/content/07_05/b4019053.htm (quoting Duncan W. Richardson, chief equity investment officer at Eaton Vance Management, saying that Section 404's internal controls testing requirements result in "even not-so-good management teams hav[ing] good controls now.").

204 See, e.g., Cost of SOX 404 Survey, U.S. Chamber of COMMERCE CenTER fOR CAPITAL MARKETS AND COMPETITIVENESS (Nov. 8, 2007), available at http://www.uschamber.com/sites/default/files/reports/0711sox_survey_report.pdf (finding that $89 \%$ of businesses surveyed expect the costs of SOX Section 404 to either "greatly exceed" or "moderately exceed" the benefits).

205 Final Report of the Advisory Committee on Smaller Public Companies, S.E.C. 33-35 (Apr. 23, 2006), available at http://www.sec.gov/info/smallbus/acspc/acspc-finalreport.pdf (showing that compliance with Section 404 cost companies with less than $\$ 100$ million in market capitalization $2.55 \%$ of the company's revenue, whereas companies with market capitalization above $\$ 5$ billion only allocate $.06 \%$ of revenue to Section 404 compliance).

206 See 17 C.F.R. $\S 210.2-02$ (f) (2013) (exempting "a registrant that is neither an accelerated filer nor a large accelerated filer" from SOX's auditor attestation requirement).

207 Sarbanes-Oxley Act of 2002, Pub. L. No. 107-204, $\S 301,116$ Stat. at 775 (codified at 15 U.S.C. $\S 78 \mathrm{j}-1(\mathrm{~m})(2)$ ) (adding Section $10 \mathrm{~A}(\mathrm{~m})(2)$ to the Exchange Act). While the audit committee had long been thought to have these responsibilities, in practice, management ended up performing most of these tasks. James R. Doty, Chairman, Public Co. Accounting Oversight Bd., Keynote Address at the 104th Annual Meeting of the Nat'l Ass'n of the State Bds. of Accountancy: A Fresh Look at Auditing (Oct. 24, 2011), available at http://pcaobus.org/News/Speech/Pages/10242011_DotyNASBA.aspx. 
rectly oversee the external auditor in auditing those financial statements. ${ }^{208}$ That means the audit committee members, on behalf of the board, are responsible for overseeing the management of operational risks associated with the preparation of financial statements and reports. However, SOX was silent as to other board functions.

Additionally, SOX mandates the independence of all audit committee members, ${ }^{209}$ as well as the disclosure of expertise on the audit committee as to accounting and financial matters. ${ }^{210}$ This independence requirement is designed to increase the board's accountability to shareholders, for if the board is more independent from management, it can better exercise its oversight role in a more neutral way. ${ }^{211}$ The expertise disclosure rule is also designed to enhance the board's ability to independently and knowledgably root out accounting manipulations. However, increased board independence may impair the board's ability to oversee - and provide guidance on-the selection of strategy. That is because a board that is more involved in and knowledgeable of the company's business and industry can more effectively oversee the setting of an effective strategy for growth. ${ }^{212}$ Without that kind of company and industry-specific knowledge by directors, it is undoubtedly a challenge for a board to effectively

208 See Securities Exchange Act of 1934, § 3(a)(58), 15 U.S.C. $\S 78 \mathrm{c}$ (2012) (defining the audit committee as a committee formed for the purpose of "overseeing the accounting and financial reporting processes of the issuer and audits of the financial statements of the issuer").

209 Sarbanes-Oxley Act of 2002, Pub. L. No. 107-204, § 301, 116 Stat. at 776 (codified at 15 U.S.C. $\S 78 \mathrm{j}-1(\mathrm{~m})(3)$ ) (adding Section $10 \mathrm{~A}(\mathrm{~m})(3)$ to the Exchange Act). In the Commission's implementing rules, it modified slightly the definition of independence. See 17 C.F.R. $\S$ 240.10A-3(b)(1). The stock exchanges also adopted independence rules at the direction of the SEC. See NASDAQ, INC., NASDAQ STOck MARKET RulES § 4350(d)(2) (2009), available at www.sec.gov/rules/other/nasdaqlicfla4_5/nasdaqllcamendrules4000.pdf [hereinafter NASDAQ Rules]; NYSE EURONEXT, INC., LISTED COMPANY MANUAL $§ 303$ A.07 (2011), available at http://nysemanual.nyse.com/LCMTools/PlatformViewer.asp?selectednode=chp_1_4\&manual=\% 2 Flcm\%2Fsections\%2Flcm-sections\%2F [hereinafter NYSE Manual].

210 Sarbanes-Oxley Act of 2002, Pub. L. No. 107-204, § 407, 116 Stat. at 790 (codified at 15 U.S.C. $\S 7265$ ); Disclosure Required by Sections 406 and 407 of the Sarbanes-Oxley Act of 2002, Securities Act Release No. 8,177, Exchange Act Release No. 47,235, 68 Fed. Reg. 5,110 (2003). Stock exchanges now require the audit committee of every listed company to contain at least one financial expert, and that all members of the audit committee be, or become, financially literate. See NASDAQ Rules, supra note 209, $\$ 4350$ (d)(2)(A) (requiring that each audit committee member be able to read and understand fundamental financial statements); NYSE Manual, supra note 209, $\S 303 \mathrm{~A} .07$ (a) (requiring that each member of the audit committee be financially literate, or become financially literate, within a reasonable period of time after his or her appointment to the audit committee).

211 See Brett H. McDonnell, Professor Bainbridge and the Arrowian Moment: A review of the New Corporate Governance in Theory and Practice, 34 DEL. J. CORP. L. 139, 170-71 (2009) (pointing to internal board dynamics, like the independence of boards, as an important part of achieving accountability).

212 See Lynne L. Dallas, The Multiple Roles of the Corporate Board of Directors, 40 SAN DiEgo L. REV. 781, 807-08 (2003). 
serve as a check on, or contribute to the formulation of, strategy; to understand what kind of processes might be necessary to effectively implement the current strategy; and even to understand what kind of controls might be necessary to identify future risks and opportunities.

While the SOX-era reform efforts focused on implementing processes designed to limit the operational risk associated with the preparation and reporting of financial statements, they generally did not attempt to regulate the amount of risk firms took on as part of their corporate strategies. In other words, SOX-era reform focused on rooting out "accounting" earnings management-or the direct manipulation of numbers or use of financial vehicles to obscure a firm's value. ${ }^{213}$ But it did not attempt to prevent "real" earnings management, or actual changes to operations in an effort to produce short-term results at the expense of long-term value creation. ${ }^{214}$ That might explain why SOX did little to control firms' implementation of highly risky corporate strategies, which lie at the heart of the 2008 financial crisis. ${ }^{215}$ The source of that crisis, and laws and regulations promulgated in its wake, are discussed next.

\section{b. $\quad$ Financial Crisis and Risk Management Requirements}

The 2008 financial crisis has been widely seen as a break-down in the process of risk management beyond the mere risk of earnings management. ${ }^{216}$

Many people believe the failed risk management practices that led to the 2008 financial crisis stemmed from flawed compensation practices that rewarded executives and other employees for short-term financial results that failed to take long-term risks into account. ${ }^{217}$ For example, when discussing the

213 See Dallas, supra note 66, at 278 (noting that the more garden-variety types of accountingearnings management involving the manipulation of accruals declined after SOX); see also Natalie Mizik, The Theory and Practice of Myopic Management, 47 J. MARKETING RES. 594, 594 (2010) (noting that accounting-based earnings management involves the manipulation of discretionary accruals).

214 See Dallas, supra note 66, at 278-79 (noting that real-earnings management has increased since the passage of SOX); see also Mizik, supra note 213, at 594 (noting that myopic management-or real earnings management-involves the over-emphasis by managers on short-term goals with immediate payoffs at the expense of strategies with superior but more distant payoffs).

215 See Dallas, supra note 66, at 278-79 (noting that real-earnings management has increased since the passage of SOX).

216 See LARCKER \& TAYAN, supra note 52, at 197.

217 See, e.g., Erica Beecher-Monas, Role of Corporate Board Executive Pay Decisions in Precipitating Financial Crisis, 11 TENN. J. BUS. L. 51, 54 (2009) ("As a result of the short-term focus on pay period rather than long-term results, as well as the heavy use of stock options in paying executives, the upside potential for profits became unlinked to the risk of loss."); Usha Rodrigues, Corporate Governance in an Age of Separation of Ownership from Ownership, 95 MINN. L. REV. 1822, 1839 (2011) (explaining how short-termism leads to the ignorance of the long-term risks of decisions and noting that " $[\mathrm{t}]$ he corporate governance reforms of both the 
executive compensation portion of the Dodd-Frank Act, Chairman Barney Frank $^{218}$ stated

[T]he [Dodd-Frank] legislation ... deal[s] with the question of the incentive structure and $\operatorname{tr}[\mathrm{ies}]$ to empower the regulators and to mandate them to so structure the rules so that people are not incentivized to take risks excessively ... whereby people take a risk and if it pays off they do well; and if they take a risk and it does not do well at all, they break even. That is not a rational incentive structure. ${ }^{219}$

Thus, much of the legislation and regulations passed in the wake of the financial crisis attempted to curb these objectionable compensation practices.

In particular, in 2009 , the SEC adopted a new rule requiring that every reporting company "address ... compensation policies and practices for all employees, including non-executive officers, if the compensation policies and practices create risks that are reasonably likely to have a material adverse effect on the company." 220 One example of such a pay practice that the SEC cited in its implementing release is where "bonuses are awarded upon accomplishment of a task, while the income and risk to the company from the task extend over a significantly longer period of time." 221

This rule is primarily intended to reveal situations where employees are paid for "performance" that fails to capture the risks from such performance. It is clearly intended to reveal pay practices at companies such as Fannie Mae, where officers made substantial performance bonuses despite their firm's significant exposure to-and ultimate realization of losses due to-risks, under-

bailout legislation and Dodd-Frank are concerned with self-interested managerial short-termism, particularly with regard to executive compensation."); Sheila C. Bair, Chairman, FDIC, Remarks to the National Press Club (June 24, 2011), available at www.fdic.gov/news/news/speeches/ chairman/spjun2411.html. The use of stock option compensation exacerbates the problem by creating an incentive for executives to make decisions to increase stock price, with no correlative loss in compensation due to decisions that decrease stock price. See Richard A. Posner, Are American CEOs Overpaid, And, If So, What If Anything Should Be Done About It, 58 DUKE L.J. 1013,1027 (2009) (arguing that with stock options, there is no ceiling on the CEO's potential gain, but the loss is truncated at the value of the options; and sometimes there is no loss because the options are repriced, enabling the CEO to exercise the option at a profit even though the corporation's stock price has fallen below the original exercise price).

218 Chairman of the House of Representatives Committee on Financial Services and sponsor for the "Dodd-Frank Act."

219 Executive Compensation Oversight After the Dodd-Frank Wall Street Reform and Consumer Protection Act: Hearing Before the H. Comm. on Fin. Servs., 11 lth Cong. 3 (2010).

220 See Proxy Disclosure Enhancements, supra note 184 (emphasis added).

$221 \quad I d$. 
mining the performance that gave rise to the bonus. ${ }^{222}$ This rule, however, does not require disclosure as to whether a firm's compensation policies and practices are designed to align pay with achievement of long-term objectives or the effective and efficient implementation of strategy. Thus, it focuses on preventing the compensation of executives for failure and not on the creation of systems to compensate executives for success.

The SEC has further attempted to limit firms' excessive risk-taking by mandating more board oversight over that process. Specifically, under a new SEC rule, public firms must disclose the extent of their board's risk management oversight role. ${ }^{223}$ This disclosure, while it does not impose a substantive requirement on boards to engage in risk management, surely suggests that boards must be doing something to oversee the management of risk. In fact, the rule contemplates that such disclosure will reveal whether the managers who are responsible for supervising risk management will report to the full board, the audit committee, or a risk committee. ${ }^{24}$ This rule does not, however, call for disclosure about their detailed structures or processes in place to manage those risks. And more relevant to this article, this rule does not call for the disclosure of the board's role in overseeing the profit-creating aspects of strategy, nor how those two oversight roles mesh together. Again, the focus of the rule is on risk oversight, without regard to the board's related strategic oversight function.

The New York Stock Exchange (NYSE) has also, to a lesser extent, attempted to prod boards into performing risk oversight. Specifically, the NYSE's corporate governance rules require audit committees of listed companies to have charters that set out the audit committee's duties and responsibilities with respect to discussing risk management policies. ${ }^{225}$ Even where the audit committee is not the sole body responsible for overseeing the management of risk, under the NYSE's corporate governance rules, it "must discuss

222 See Jesse Fried \& Nitzan Shilon, Excess-Pay Clawbacks, 36 J. CORP. L. 721, 734-35 (2011) (noting that even after then-CEO Franklin Raines departed Fannie Mae in 2004 after an earnings-manipulation scandal, he was allowed to keep millions in bonus compensation tied to inflated earnings). In fact, regulators alleged that \$52 million of Raines's \$90 million compensation from 1998-2003 was tied to bonus targets that were achieved because of manipulative accounting. Eric Dash, Fannie Mae to Restate Results by $\$ 6.3$ Billion Because of Accounting, N.Y. TIMES (Dec. 7, 2006), http://www.nytimes.com/2006/12/07/business/07fannie.html.

223 See 17 C.F.R. $\$ 229.407$ (2013).

224 Id.

225 NYSE Manual, supra note 209, 3 303A.07(b)(iii)(D). The NASDAQ does not contain a similar requirement, and does not appear to contain any other special corporate governance rules regarding the management of, or oversight over the management of, risk. See NASDAQ Rules, supra note $209, \S \S 5600-5699$. 
guidelines and policies to govern the process by which risk . . management is undertaken., 226

While this rule suggests that the audit committee oversees all aspects of firm risk management, under the NYSE's rules, the audit committee's function is to oversee the integrity of a listed firm's financial statements, as well as its compliance with law. ${ }^{227}$ Thus, this committee's risk oversight function is most likely limited to overseeing risks that are contemplated by ICOFR, and not strategic risks. Yet the fact that its charter requires it to discuss guidelines and policies that relate to risk management without limiting it to financial risk suggests that it is seen as the default body to oversee risk at the firm.

\section{SPURRING STRATEGIC MANAGEMENT THROUGH SECURITIES LAWS}

Despite their common purpose and interrelated function, as I have shown in Part III, risk and strategic management processes are treated quite differently under federal securities mandates. The primary reason securities mandates do not require disclosure of a firm's strategy is because such disclosures might impair a firm's competitive advantage. Yet it is not at all clear that some limited disclosure about that firm's strategic management process would reveal anything substantive about its strategy.

The next Section-Section A-traces through all of the reasons lopsided disclosure about risk and strategic management is problematic. It also examines how certain information about strategic management can in fact be disclosed without compromising a firm's competitiveness. Then, Section B proposes a way to provide investors with more information about strategic management processes, as a mechanism to prod firms to more effectively engage in that critical, wealth-creation process.

\section{A. Concerns with Lopsided Disclosure of Risk and Strategic Management}

Firms' disclosure of information about their risk management processes without any equivalent disclosure of their strategic management processes is concerning for a number of reasons.

First, it could lead to disjointed risk and strategic management processes. In particular, firm risk management processes implemented as a result of disclosure obligations might not effectively function alongside related, yet unregulated, strategic management processes, undermining the necessary interplay between those two processes. ${ }^{228}$ While disclosure does not necessarily dic-

\footnotetext{
226 NYSE Manual, supra note $209, \S 303 \mathrm{~A} .07(\mathrm{~b})(\mathrm{iii})(\mathrm{D})$.

227 Id. $\S 303 \mathrm{~A} .07(\mathrm{~b})(\mathrm{i})(\mathrm{A})$.

228 See Francis K. Achampong, Integrating Risk Management and Strategic Planning, PLANNING FOR HIGHER EDUCATION 22-23 (2010), available at http://wwwl .scup.org/PHE/FMPro?-db=PubItems.fp5\&-lay=ART\&-format=read_full.htm\&-
} 
tate firm conduct, that is usually the intended effect, as firms try to avoid making embarrassing or unusual disclosures. And to the extent firms do change their risk management processes in response to disclosure requirements, it is not at all clear that firms would-or should-change affected aspects of their strategic management process. Yet making such changes to strategic management processes, even if unwise from a process perspective, may be required so that there continues to be a coherent and comprehensive system in place for the creation of value.

As an example, consider the NYSE's requirement that the audit committee discuss annually its policies for managing risk. ${ }^{229}$ While commentary states that the audit committee need not be the "sole" body responsible for risk management, ${ }^{230}$ the fact that this committee is responsible for discussing policies for managing risk suggests that the audit committee is expected to play a role-the central role, in fact-in overseeing that process. This rule, approved by the SEC in $2003,{ }^{231}$ may be one of the reasons firms typically task their audit committees with overseeing the management of risk. ${ }^{232}$ Undoubtedly, it makes sense to task the audit committee with overseeing operational risk associated with the preparation of financial statements and reports. ${ }^{233}$ However, it is less clear that the audit committee should exclusively, or even primarily,

error=error.htm\&ID_pub=PUB-xiDNfxGI3PdWDcp2wc\&t_Pub_PgNum=22\&-Sort-

Field=t_Pub_PgNum\&-Find ("In the final analysis, the ultimate goal of efforts to maximize an institution's value (through risk management) and set its strategic goals and objectives (through strategic planning) is the achievement of the institution's expressed vision. In light of that, it is both logical and desirable to integrate risk management and strategic planning into one coordinated, holistic process to create a synergistic effect that leverages the benefits of both processes and makes them mutually reinforcing.").

229 See supra note 225 and accompanying text.

230 See supra note 226 and accompanying text.

231 Order Approving NYSE and NASD Proposed Rule Changes Relating to Corporate Governance, 68 Fed. Reg. 63,983, 64,154-59 (Nov. 12, 2003).

232 See Matteo TONello, Emerging Governance Practices IN ENTERPrise Risk MANAGEMENT 8 (The Conference Board Research Report No. R-1398-07-WG, 2007) ("Research indicates that two-thirds of companies currently delegate risk oversight responsibilities exclusively to the audit committee."). For a study of who on the board oversees the management of risk at Fortune 500 companies, see AKIN GUMP STRAUSS HAUER \& FELd LLP, CORPORATE Alert: THE BOARD'S ROLE IN RISK OVERSIGHT: A SURVEY OF RECENT PROXY STATEMENT DisClOSURES (Apr. 10, 2010), available at http://cdn.akingump.com/images/content/6/5/v4/6507/100406-The-Boards-Role-in-Risk-

Oversight.pdf (finding that $22 \%$ of companies within the Fortune 500 identified the audit committee as the committee primarily responsible for overseeing the management of risk, in comparison to $8 \%$ who identified the full board as primarily responsible for this oversight; the rest responded a combination of board and committee oversight).

233 See supra notes 202, 207-12 and accompanying text (discussing various securities mandates aimed at ensuring the audit committee can effectively perform its accounting and financial oversight function). 
oversee strategic risk, or the risk that a firm's products will become obsolete, consumer preferences will change, or some other change will occur that undermines the effectiveness of the firm's strategy in protecting its competitive position. ${ }^{234}$

A more troubling concern is that the NYSE rule fails to address how boards should oversee the management of strategy where the audit committee oversees the management of risk. As such, the full board might not have the information about risk that it needs to effectively perform its strategic oversight function. ${ }^{235}$ Similarly, the audit committee might not have the skills, resources and information it needs to be able to understand strategic risk, or how information about risk feeds into the strategic management process. This is especially true given that the audit committee must be comprised of only outsiders, ${ }^{236}$ none of whom would be as familiar with a firm's strengths, resources, and other strategic considerations as an insider. Thus, regulations directed at implementing a particular risk management structure-whether stemming from stock exchange or SEC rules-could lead to the implementation of a risk management structure that impairs the performance by the managers or the board of their respective strategic management functions.

As another example, consider the legislation that Senator Charles E. Schumer introduced in 2009 called the Shareholder Bill of Rights Act of $2009 .{ }^{237}$ Under that proposed legislation, all public companies would have been required to form risk committees of the board "responsible for establishing and evaluating the firm's risk-management practices." ${ }^{, 238}$ Despite the fact that that legislation was never passed, more and more companies are putting such committees in place, in part because such committees are now required for many financial institutions under the Dodd-Frank Act. ${ }^{239}$ While there may be

\footnotetext{
234 See LARCKER \& TAYAN, supra note 52, at 195 (noting, in the context of a discussion of risk committees, that the audit committee focuses on risks associated with financial results and accounting statements rather than with operations); Mark L. Frigo \& Richard J. Anderson, What is Strategic Risk Management?, STRATEGIC FIN. (Apr. 2011), at 21-22, available at $\mathrm{http}: / / \mathrm{www} . \mathrm{markfrigo.com} /$ What_is_Strategic_Risk_Management_-_Strategic_Finance__April_2011.pdf.

235 See LARCKER \& TAYAN, supra note 52, at 195 (stating this concern where a risk committee, rather than the full board, is charged with overseeing the management of risk).

236 See supra note 209 and accompanying text.

237 See Shareholder Bill of Rights Act of 2009, S. 1074, 111 th Cong. $§ 5$ (2009).

238 Id.

239 Carol Beaumier \& Jim Deloach, Risk Oversight: Should Your Board have a SEPARATE RISK COMMITTEE? 2 (Jan. 2012), available at http://www.conferenceboard.org/retrievefile.cfm?filename=TCB-DN-V4N1-12.pdf\&type=subsite (noting that there may be a "trickle-down effect" of the Dodd-Frank Act's requirement of a separate risk committee to nonfinancial companies); see also Dodd Frank Wall Street Reform and Consumer Protection Act, Pub. L. No. 111-203, \& 165, 124 Stat. 1376, 1423 (2010).
} 
merit to having such a board structure at some companies, ${ }^{240}$ at others, this structure could impair the board's ability to oversee the setting of strategy for reasons similar to those discussed in the preceding paragraph. Namely, the directors who are not on the risk committee might not be adequately aware of or understand either the kinds of risks inherent in potential strategies or the processes in place to manage those risks. ${ }^{241}$ In fact, these and other similar concerns led The Conference Board, a respected business research association, to suggest that full boards (rather than risk or audit committees) oversee both risk and strategic management processes. ${ }^{242}$

Second, the absence of mandated disclosure of processes to manage strategy, especially as compared to processes to manage risk, inevitably leaves boards and officers with the impression that the latter is more important than the former. This inevitably causes managers to devote more resources to risk management processes to comply with legal requirements, and to skimp on resources for strategic management processes. ${ }^{243}$ For example, according to a survey of executives conducted by the Economist Intelligence Unit

[R]espondents point to controls and monitoring, and compliance as taking up the largest proportion. By contrast, they say that horizon scanning and spotting opportunities typically consume far less resources - probably because there is little time left once the controls and compliance obligations are met. ${ }^{244}$

The NYSE, in a 2010 report issued by its Commission on Corporate Governance, has also cautioned that new governance mandates and "best prac-

240 See BEAUMIER \& DELOACH, supra note 239, at 2 (identifying such companies as financial institutions, power companies, and other organizations with complex market, credit, liquidity, commodity pricing, regulatory and other risks that require special attention).

241 See id.; Norges Bank Investment Management, Letter to the SEC Regarding Proxy Disclosure and Solicitation Enhancements, 2009 WL 3235200 (Sept. 14, 2009) [hereinafter Norges Bank Comment Letter] ("As risk management should be seen as an integral aspect of strategy evaluation, execution, control, and communication we would like to caution that while establishing a board risk committee can sometimes be useful it will not free the board from treating risk as integrated in most of its decision making.").

242 See BEAUMIER \& DeLoACH, supra note 239 , at 1.

243 See LARCKER \& TAYAN, supra note 52, at 186-88.

244 Phil Davis, Beyond Box-ticking: A New Era for Risk Governance, THE ECONOMIST INTELLIGENCE UNIT 16-17 (2009), available at http://www.kpmg.com/ZA/en/lssuesAndInsights/ArticlesPublications/Financial-Services/Documents/Box\%20Ticking.pdf. Professor David Larcker, affiliated with the Corporate Governance Research Program at the Stanford School of Business, has also said disapprovingly that a check-the-box mentality associated with compliance is drowning out strategy. See Stanford Univ., Why Does Corporate Governance Really Matter? New Book from Stanford Showcases Research into How Boards Can Govern Better, CORPORATE GOVERNANCE \& LEADERSHIP WIRE (May 19, 2011, 1:47 PM), http://www.stanford.edu/group/gsb_corpgov/cgi-bin/blog/?cat=55. 
tice" recommendations over the last decade create a risk that even the best boards will adopt a check-the-box mentality rather than having corporate governance serve an integrated role in a company's strategy. ${ }^{245}$ If managers and the board are indeed spending a disproportionate amount of time on box-checking compliance activities and not on ensuring the firm has adopted and is implementing an effective strategy for growth, this is quite troubling. To effectively create value, firms need to engage in both the wealth-creating process of strategic management, in addition to the wealth-protecting process of risk management.

SOX's requirements as to internal control over financial reporting (ICOFR) exemplify this concern. To refresh, under SOX, a firm's management must assess and report on the effectiveness of the firm's ICOFR, and the auditor must then attest to and report on management's assessment. ${ }^{246}$ In addition, the CEO and CFO must certify as to the effectiveness of a firm's ICOFR ${ }^{247}$ However, ICOFR excludes controls designed to provide reasonable assurances about the implementation of strategy. ${ }^{248}$ It also excludes control systems designed to ensure managers receive relevant and timely information necessary to select strategy or change strategy in response to a new opportunity. $^{249}$

Firms continue to incur significant costs and devote significant efforts to complying with ICOFR requirements. ${ }^{250}$ In fact, numerous commentators

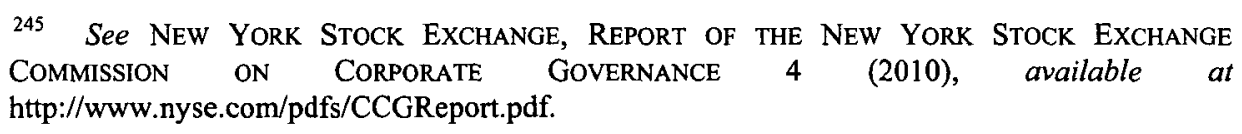

246 See supra notes 199, 202 and accompanying text.

247 See supra notes $200-01$ and accompanying text.

248 See supra notes 196-98 and accompanying text.

249 COSO's ERM framework would include the latter step in the process. See THE COMMITTEE of SPONSORING ORganizations of tHE TREadWAy COMMISSION (COSO), ENTERPRISE RiSK MANAGEMENT - INTEgRATED FRAMEWORK, EXECUTIVE SUMMARY 2 (2004), available at http://www.coso.org/documents/coso_erm_executivesummary.pdf [hereinafter COSO ERM FRAMEWORK]. However, most companies have not yet implemented COSO's ERM. See MARK S. BEASLEY ET AL., COSO'S 2010 REPORT ON ERM: CURRENT STATE OF ENTERPRISE RISK OVERSIGHT AND MARKET PERCEPTIONS OF COSO's ERM FRAMEWORK iii (Dec. 2010), available at http:/www.coso.org/documents/COSOSurveyReportFULL-Web-R6FINALforWEBPOST ING111710.pdf (finding from a study that only $28 \%$ of survey respondents reported implementing ERM systems that were systematic, robust and repeatable, and 60\% reporting risk tracking that is mostly informal and $a d h o c$ ). Still, that framework does not cover all aspects of strategic management; thus a firm would still need a separate strategic management framework to formulate strategies as a result of information provided as part of the ERM. COSO ERM FRAMEWORK, supra note 249 . These controls are also not required to be implemented under state law, for oversight duties only call for controls to bring relevant information to managers and the board about the risk of a violation of law or wrongdoing. Grossman, supra note 15, at 485-86.

250 See J. Robert Brown, Criticizing the Critics: Sarbanes-Oxley and Quack Corporate Governance, 90 MARQ. L. REV. 309, 321 n.65 (2006) ("The most significant cost of [SOX], one 
and policy-makers have questioned whether these rules add more costs than benefits. ${ }^{251}$ To the extent compliance with these rules necessitates a significant amount of managers' energy and time, that translates into time and energy not spent on profit-generating activities. That is not to say that such rules do not have benefits, for surely a firm and its constituents benefit where that firm has internal controls designed to prevent violations of law or accounting mischief. However, any measure of costs must include lost managerial time from wealthenhancing measures, and the costs of having firms institute separate control systems for the management of the wealth-creating aspects of strategy and those designed to protect that wealth through controlling risk.

The rule requiring firms to disclose whether their compensation policies and practices create risks that are reasonably likely to have an adverse effect $^{252}$ also raises this concern. In particular, that rule tells companies that they need to ensure their compensation policies and practices in fact do not create such adverse risks. However, it fails to send any message encouraging such firms to tie compensation to the achievement of strategic goals, or the effective implementation of strategy. Surely this is a desirable outcome, especially in the current environment in which "pay for performance" is emerging as a best practice. Yet if, as a policy matter, executives should be paid for positive performance, then the law should encourage this outcome rather than simply ensuring they are not paid for non-performance.

Third, if managers become accustomed to engaging in a check-the-box exercise to ensure compliance with risk-based process regulations, that could prevent them from thinking outside of the box, so to speak, in creating unique and innovative new strategic processes designed to create wealth. That, in turn,

occasionally mentioned by others but not discussed in great detail, may be the opportunity costs associated with CEO and CFO review in connection with the certification process. To the extent officers decide to undertake substantial due diligence in connection with the process, this is time taken away from running the business."); see also Paul S. Atkins, Commissioner, SEC, Remarks Before the International Corporate Governance Network 11th Annual Conference (July 6, 2006), available at http:// www.sec.gov/news/speech/2006/spch070606psa.htm (noting that Section 404 is the law's most costly provision because of the ways in which accountants and managers have implemented it). But see Brett H. McDonnell, In the Wake of Corporate Reform: One Year in the Life of Sarbanes-Oxley-a Critical Review Symposium Issue, 2004 MiCH. ST. L. REV. 505, 513 (2004) ("These [referring to SOX's] internal control requirements go somewhat beyond existing law, but not all that far beyond.").

251 See supra note 204 and accompanying text; see also Anna Fifield, Greenspan Predicts U.S. Governance Revamp, FIN. TIMES, April 13, 2006, at 1. Some of the costs associated with compliance are expected to be reduced by the FASB's recent adoption of Auditing Standards 5, which greatly simplifies the guidance given to management and auditors on how to test the effectiveness of ICOFR. Press Release, Sec. \& Exch. Comm'n., SEC Approves PCAOB Auditing Standard No. 5 Regarding Audits of Internal Control over Financial Reporting; Adopts Definition of "Significant Deficiency" (July 25, 2007), available at http://www.sec.gov/news/press/2007/2007-144.htm.

252 See supra note 220 and accompanying text. 
would run counter to a statement made by President Obama highlighting the need for the U.S. to resume its role as a leader in innovation. ${ }^{253}$ While that is not to say that firms should ignore risk in pursuit of innovation, it does suggest that durable innovation requires a balancing of risk with potential returns as part of the strategic management process, and that innovation requires a certain amount of creative thought. Thus, we should be encouraging firms to engage in responsible risk-taking activities intended to generate long-term value, rather than excessive caution in light of more extensive risk-based regulation, and couple that with appropriate disclosure so investors can gauge for themselves the appropriateness of that firm's approach to wealth-creation for their portfolios.

Fourth, instituting disjoined risk and strategic management processes in response to lopsided disclosure rules flies in the face of Enterprise Risk Management (ERM). ERM promotes taking an enterprise-wide, holistic, top-down approach to managing risk. ${ }^{254}$ It is also what many view as the future of risk management. ${ }^{255}$ ERM recognizes that managing risk is essential to managing strategy, for it helps ensure that opportunities are discovered and timely fed into the strategic planning process. ${ }^{256}$ In fact, the goal of ERM is to make risk part of the discussion of strategy. ${ }^{257}$ Unfortunately, federal disclosure rules that consider risk management entirely separately from strategic management validate independent processes that belie ERM's holistic and integrated management approach. Thus, federal securities laws help explain why most companies have not yet integrated their risk and strategic management functions. ${ }^{258}$

Fifth, lopsided disclosure of risk and strategic management processes gives investors a misleading picture into processes designed to create firm value. That is because such lopsided disclosure gives investors an incomplete picture of the interrelatedness between risk and strategic management processes, which are designed to together create value. On one hand, it tells investors how a firm manages its risk of loss from future deviations from the cur-

253 See, e.g., Barack Obama, President, United States of America, State of the Union Address (Jan. 29, 2011) ("The first step in winning the future is encouraging American innovation... .What we can do-what America does better than anyone else-is spark the creativity and imagination of our people. We're the nation that put cars in driveways and computers in offices; the nation of Edison and the Wright brothers; of Google and Facebook. In America, innovation doesn't just change our lives. It is how we make our living.").

254 JAMES W. DELOACH, ENTERPRISE-WIDE RISK MANAGEMENT: STRATEGIES FOR LINKING RISK AND OPPORTUNITY Xiii (2000); ROBERT R. MOELLER, COSO ENTERPRISE RISK MANAGEMENT: UNDERSTANDING THE NEW INTEGRATED ERM FRAMEWORK 3 (2007).'

255 See, e.g., Simkins \& Ramirez, supra note 14, at 583-84.

256 See ELLEN HEXTER, RISKY BuSINESS: Is ENTERPRISE RISK MANAGEMENT LoSING GROUND? 20 (The Conference Bd. 2007) [hereinafter HEXTER, RISKY BUSINESS].

257 TONELLO, supra note 232, at 7.

258 HEXTER, RISKY BUSINESS, supra note 256 , at 8. 
rent plan. On the other hand, it fails to tell investors anything about the processes through which the plan from which a firm might deviate was created and executed.

In fact, the absence of information about how strategy is managed in light of current disclosure about how risk is managed might make the latter disclosure more opaque. In other words, investors might be less informed about a firm's governance structure to manage risks if they do not know anything about the processes through which those risks were created in the first place.

That is not to say that investors must be told everything about a firm's strategic management process; in fact, despite the large swath of information investors currently receive from public firms, they are given only limited information about risk management processes. ${ }^{259}$ However, that information is simply incomplete without disclosing, for example, how that process interplays with the strategic management process, and similarly, about how the process of creating and implementing strategy relates to the disclosed aspects of risk management.

For example, under the proxy enhancement rules implemented following the 2008 financial crisis, firms must disclose the role of their boards in overseeing the management of risk. ${ }^{260}$ This requirement makes it clear that the board should play a role-undoubtedly viewed as an important role, given that federal securities laws generally only require the disclosure of "material" information-in overseeing the management of risk. However, firms do not need to disclose any information about the board's role in overseeing the firm's strategic management process. $^{261}$ Such mismatch in disclosure might lead investors to believe that the board does not play any part in overseeing strategy, for if it did, such disclosure would surely be included. It also tells only part of the story about board oversight over firm processes to create value. After all, why should board oversight over processes to manage risk to limit losses be more important to investors than board oversight over processes to generate gains? The fact that recent corporate crises stimulated this disclosure requirement should not mean the requirements should not also address board oversight over value-creation more broadly, especially where failing to do so gives investors a misleading picture of the board's function within the firm.

\footnotetext{
259 See discussion supra Section III.B.

260 See supra note 223 and accompanying text.

261 See Norges Bank Comment Letter, supra note 241 ("We would like to emphasis [sic] that board level risk management should be seen primarily in the context of the board's role in corporate strategy development. We would expect the board to understand and evaluate the market risk, credit risk and other business risk material to the activities of the company as part of the strategy process. . . . As risk management should be seen as an integral aspect of strategy evaluation, execution, control, and communication we would like to caution that while establishing a board risk committee can sometimes be useful it will not free the board from treating risk as integrated in most of its decision making.").
} 
The SEC has, on occasion, promulgated rules that give investors a more complete picture of risk and strategic management, including their interconnectedness. For instance, under CD\&A, firms must disclose their bases for awarding compensation, including, for long-term compensation, the basis for allocating compensation to each different form of award. ${ }^{262}$ According to the applicable rule, this includes information about the relationship of the compensation award to achievement of long-term goals, as well as management's exposure to downside equity performance risk. ${ }^{263}$ In other words, this disclosure does not merely call for information about compensation practices related to risk, but also about such practices related to the achievement of positive strategic objectives. Understanding that this disclosure might undermine the secrecy of a firm's strategy, the SEC instructed firms how to provide this disclosure in a way that would not result in competitive harm. ${ }^{264}$ In that way, it did not confine the disclosure to only address the problematic relationship between compensation and risk, likely because that would have given investors an incomplete sense for a firm's compensation policies and practices.

A final concern is that without a good sense for the processes that a firm employs to create value, investors inevitably will continue to look to earnings forecasts for insight into firm efforts to generate gains. Reliance on those forecasts, in turn, causes investors to pressure managers to focus their efforts not on processes to create sustained value, but on processes to meet or beat the numbers in those forecasts, regardless of how that affects the firm in the long-term. ${ }^{265}$ That is not to say the information about a firm's strategic management efforts would eliminate this problem, for undoubtedly investors will continue to apply such pressure on managers to generate short-term returns so long as they receive such forecasts. However, those efforts may not be as successful if management felt some pressure to adhere to disclosed processes for the creation of long-term value to avoid anti-fraud liability. Moreover, more public attention on long-term management processes may also enhance their image and perceived value to investors.

Still, these concerns might not dictate that firms disclose their strategic management processes if requiring such disclosure could ruin a firm's competitive advantage. However, the confidentiality of a firm's strategy does not necessarily mean that its strategic management process is confidential. In fact, one of the primary reasons why the former is protected is because it allows a firm to not tip its hand to its competitor as to its future plans for creating wealth. A firm's strategic management process, in contrast, is not a future plan but rather

\footnotetext{
262 See supra notes 97-99 and accompanying text.

263 Id.

264 See supra notes 100-102 and accompanying text.

265 See Mei Cheng et al., Earnings Guidance and Managerial Myopia 2-3 (Nov. 2005), (unpublished manuscript), available at http://ssm.com/abstract=851545.
} 
a current process. Therefore, it does not reveal the direction the firm is headed. Moreover, information about strategic management processes would not seem to be any more confidential than information about risk management processes. Yet Congress and the SEC have carefully laid out what firms must disclose about risk management so as to not force firms to disclose their strategies. Finally, the fact that some aspects of a firm's strategic management process might be confidential does not mean that the entire process is confidential. It simply counsels caution when designing a disclosure rule. Again, the fact that firms must disclose the level of board oversight over strategic management processes in response to shareholder requests for such information ${ }^{266}$ clearly indicates that some aspects of strategic management processes can be disclosed, while others can remain protected.

Given the extent of concerns raised above with firms providing imbalanced disclosure of risk and strategic management, and the fact that providing limited information about strategic management would not necessarily contravene a firm's need to maintain the secrecy of its strategy, there needs to be a shift in the securities legal regime pertaining to strategic management. My proposal for addressing these concerns is discussed next.

\section{B. Disclosing Strategic Management: A Proposal}

To address the concerns resulting from a mismatch in disclosure on risk and strategic management processes mentioned above, I propose a change in current SEC disclosure rules. Specifically, I propose that existing SEC rules be broadened to require public firms to disclose aspects about their strategic management processes that are equivalent to disclosed aspects of risk management processes. Moreover, under those same rules, firms should have to explain how disclosed aspects of their risk management and strategic management processes work together to create firm value.

To see my proposal in action, recall that under current SEC rules, firms currently must disclose the role of the board in overseeing the management of risk. Under my proposal, pursuant to an amended version of that rule, a firm would also need to disclose the board's role in overseeing the management of strategy. Thus, investors of that firm would be able to make some judgment as to board oversight over those processes based on, for example, whether the entire board performed both oversight functions, or part of those oversight responsibilities were delegated to a board committee.

In addition, the firm would have to explain how the board's risk management oversight role related to its strategic management oversight role. If, for instance, a firm disclosed that its board oversaw the management of strategy but also disclosed that its audit committee oversaw the management of risk, the

See supra notes $178-80$ and accompanying text. 
firm would also have to explain how the board fulfills its strategy oversight function in light of the fact that the full board does not oversee risk. If the audit committee regularly reported on risk to the full board, for instance, then that would have to be disclosed so that investors could understand how the board discharged its strategic oversight function without serving as the key risk overseer. ${ }^{267}$

My proposal would also call for additional disclosure under ICOFR. Specifically, as I explained in Part III, the current focus of ICOFR is to ensure the reliability of a firm's financial reporting and the preparation of financial statements for external purposes. ${ }^{268}$ It does not, however, regulate control over the implementation of a firm's strategic plan. Thus, I propose that the SEC expand the definition of ICOFR to include such control. While this would expand on SOX's definition of ICOFR, SOX does not appear to limit the SEC's ability to expand on the concept to capture related controls. Again, this change would reflect the fact that controls are necessary not only to avoid accounting manipulations and financial misstatements, but also to ensure a firm's employees implement the strategy that has been selected for the organization, instead of making decision on the basis of their own compensation or other factors.

That being said, it does not seem necessary to require external auditors to attest to the component of control tied to strategy implementation, as those auditors generally focus on accounting and financial controls. ${ }^{269}$ Rather, this proposal could be implemented by including strategy implementation controls within the scope of ICOFR for purposes of managers' annual ICOFR assessment and report, as well as for the CEOs' and CFOs' ICOFR certifications. That way, investors would be given some assurances about a firm's commitment to ensuring its employees implement the firm's strategy from the individuals who are responsible for overseeing that aspect of the strategic management process without forcing a firm to disclose exactly how it structures that process.

While the above examples explain how the SEC could modify its existing rules to reflect my proposal, my proposal is not intended to be limited to current rules. Thus, under my proposal, if the SEC were to promulgate new rules requiring disclosure of risk management processes, it would also need to incorporate into those rules disclosure intended to reveal related aspects of

\footnotetext{
267 CalPERS, the largest public pension fund in the U.S., promoted such a balanced approach to disclosure in its comment letter to the SEC. See Letter from Anne Simpson, Senior Portfolio Manager of Global Equity, to Elizabeth Murphy, SEC Secretary (Sept. 16, 2009), available at http://www.sec.gov/comments/s7-13-09/s71309-146.pdf ("To balance this [referring to its proposal for more information about the board's process for identifying, elevating and monitoring risk on a holistic basis], the disclosure should be linked clearly to the company's strategy for value creation....").

268 See supra notes 196-98 and accompanying text.

269 Codification of Accounting Standards and Procedures, Statement on Auditing Standards No. 1, § 110 (Am. Inst. of Certified Pub. Accountants 1972).
} 
strategic management processes, and how that interplays with disclosed risk management processes.

This proposal would cure the problems I highlighted above with the current disclosure regime. Specifically, it would dispel any notion that risk management is a stand-alone function performed independently from strategic management, as both processes would be disclosed together, with an emphasis on their relationship. It would also send the message to companies that regulators-acting to protect investors' voting and financial interests - care not only about processes to protect value, but also about processes to generate value. It would also avoid giving firms the impression that risk management is more important than strategic management. This, in turn, might spur firms to devote more resources to setting and executing on their strategies, with more awareness of, and hopefully appreciation for, the intricacies of those processes.

My proposal would also be consistent with the existing regime under federal securities laws, which often encourages best practices through transparency rather than through mandates on specific conduct. ${ }^{270}$ In that way, no single strategic management process would be imposed on firms, allowing them to continue to experiment and improve their processes.

The new disclosure under my proposal would also give investors some basis to hold managers accountable under their fiduciary duties for failing to follow through with the strategic management processes they disclose. While fiduciary duty law would not currently provide the basis for such a suit, under a proposal I made in a prior article, directors and officers could be held liable for breaching their duty of oversight as a result of the failure to engage in strategic management processes. ${ }^{271}$ Thus, this proposal would provide the information that investors would need to enforce the duties I proposed in that other article.

This benefit, too, counsels in favor of increasing disclosure of strategic management processes rather than removing current risk management disclosure requirements. That is because a balanced, non-disclosure approach would fail to ensure investors regularly received the kinds of information they would need to enforce these fiduciary duties.

My proposal will also hopefully spur firms to engage in long-term planning, which lies at the heart of strategic management. It would do that by essentially forcing firms to take those strategic steps that they disclose to in-

\footnotetext{
270 Ripken, supra note 16, at 151 (explaining the indirect influence disclosure has on corporate decision-making without necessitating the adoption of substantive rules of conduct). The Sarbanes-Oxley Act's rule requiring public firms to disclose whether or not they had adopted a Code of Ethics meeting SOX's specifications is an example of a disclosure mandate that attempts to change corporate governance practices. In that instance, firms adopted Codes that complied with SOX en masse to avoid having to disclose why they failed to have such codes in place. See DELOITTE, BuSINESS ETHICS AND COMPLIANCE IN THE SARBANES-OXLEY ERA 1 (2003), available at http://www.whistleblowing.com.au/information/BusinessEthicsComplianceinSOXEra.pdf.

27 See Grossman, supra note 15 , at $495-506$.
} 
vestors as part of their strategic management process. While simply engaging in strategic management does not by itself assure a firm sustained success, it does help firms to be more deliberate and intentional in creating their long-term plans. This, hopefully, would lead to more effective long-term plans.

Still, this proposal is no panacea for short-termism. That is because, as I discussed above, it is not just the absence of effective strategic management efforts that underlie short-termism. ${ }^{272}$ In fact, arguably my proposal will exacerbate the problem of short-termism, for it could paint a target on those companies that invest in long-term planning. Short-termists would then be able to press those companies for changes in their policies and strategies to bring about more short-term results.

While that may be one possible effect of my proposal, the information that would be called for under my proposal would not necessarily displease short-term shareholders. That is because even short-term shareholders might support organizations with more deliberate and carefully designed management systems in place, even if those systems are focused on generating long-term value. In fact, increased transparency about processes designed to generate wealth over time would likely lead to an increase in current stock prices, as investors typically calculate a firm's present value on the basis of its future earning potential. ${ }^{273}$ Thus my proposal-designed to foster more effective longterm planning - would not necessarily provide fodder to short-term shareholders seeking to extract more profits out of firms in the short term. ${ }^{274}$

Furthermore, while my proposal does not purport to remove the market-distorting factors driving managerial myopia, it would supplement those proposals. It would do that by buttressing firm efforts to strategically plan and grow to create sustained wealth. With more emphasis on such strategic processes, investors could rely more on information disclosed about those processes and less on quarterly earnings forecasts in making their investment and voting decisions.

Refocusing firms on the management of strategy might also lead to a closer association between incentive compensation and achievement of the long-term objectives or strategies that are part of their strategic plans. That is because as firms are driven to engage in more long-term planning as a result of disclosure, they will hopefully spend more time creating effective long-term goals that can be used as performance targets. That might, in turn, decrease

\footnotetext{
272 See discussion supra Section II.B.

273 See supra note 139 and accompanying text.

274 In any event, in its rules effectuating my proposal, the SEC would need to be sensitive to the fact that short-term shareholders might use the new information in a way that undermines long-term planning. Thus, it would need to carefully craft rules to avoid that outcome.
} 
boards' tendencies to rely on stock-based compensation, which has been found to lead to short-termism, ${ }^{275}$ to reward managers.

My proposal would also preserve the confidentiality of a firm's strategy. As I discussed above, many firms derive value from the fact that their strategies are confidential. ${ }^{276}$ This proposal would protect that secrecy by focusing on the disclosure of identified, current processes rather than the disclosure of substantive, forward-looking plans. Yet it would allow investors to draw some conclusions about the strength of a firm's strategy by looking at the strength of its strategic management process.

Still, critics will undoubtedly argue that some information about the strategic management process should remain secret. ${ }^{277}$ That is because such secrecy can help a firm avoid undue criticism and second-guessing with respect to its process. ${ }^{278}$

However, the downsides to maintaining the secrecy of a firm's strategic management process would seem to outweigh these benefits. For example, such secrecy might undermine the benefit of having open communications, not solely with insiders, but also with non-employee stakeholders, especially in the strategy formulation process. ${ }^{279}$ In addition, as I argue above, such secrecy might undermine the ability of constituents like shareholders to hold managers accountable for their deficient processes.

Further, it seems unlikely that the information that would be disclosed under my proposal would be any more confidential than the equivalent information that is provided about risk management processes. That is because both processes undergird a firm's creation of value. The primary difference is whether the process focuses on limiting losses (risk management) or on creating gains (strategic management). Yet critics have not suggested that the information that is currently provided about risk management processes is, or should be, confidential. In fact, the SEC might have switched its focus from requiring disclosure of substantive risk to requiring disclosure of risk management processes to prevent challenges such as those made to Item 305 of Regulation S-K - that information about risk may actually reveal confidential aspects of strategy.

Moreover, the SEC already precludes firms from excluding from their proxy statements shareholder proposals calling for information about the board's role in overseeing a firm's strategy, undermining the argument that such information relates to the firm's ordinary business operations. ${ }^{280}$ And

\footnotetext{
275 See supra note 217 and accompanying text.

276 See supra notes 164-167 and accompanying text.

277 DAVID, supra note 84 , at 302.

$278 \quad I d$.

279 See id.

280 See supra notes $178-80$ and accompanying text.
} 
based on the nature of firms' challenges to those requests, they do not view their strategic management oversight structures-a key components of that process-as confidential.

In any event, to the extent a firm did view as confidential an aspect of its strategic management process that would be required to be disclosed under my proposal, the SEC has already shown that it can be sensitive to firms' needs to maintain information about strategy confidential. Namely, it has protected such confidential information through the design of its rules, its commentary to specific rules that might be interpreted as compromising the confidentiality of such information, ${ }^{281}$ and applying an exemption from disclosure when necessary. ${ }^{282}$ Thus the SEC could - and would be expected to-continue to protect the secrecy of any confidential information that would be called for under my proposal.

Relatedly, critics might argue that there would be a burdensome duty to update the information called for under my proposal. ${ }^{283}$ However, the information called for under my proposal is about a current process in place-or at least about specified aspects about that process. Thus, unlike with forwardlooking information, the future will not change the accuracy of disclosed aspects of a firm's strategic management process.

If a firm does materially change a disclosed aspect of its strategic management process, indeed the firm would have to disclose such change. ${ }^{284}$ However, the burden of making such disclosure would be no greater than the burden that already exists on public companies to ensure, through their periodic reports, that their investors receive all material information about them. And this burden seems light in comparison to all of the other benefits of such disclosure mentioned above.

In addition, critics might argue that the new disclosure I propose will inevitably evolve into generic boilerplate. Such boilerplate disclosure may not be useful to investors in making investment decisions.

However, the information that firms provide about their board's role in overseeing risk management is varied. ${ }^{285}$ Moreover, such information has

\footnotetext{
281 See supra note 101 and accompanying text.

282 See supra note 96 and accompanying text.

283 See discussion supra Section III.A.

284 Presumably this would be required to be reported on the firm's subsequently filed periodic report, or as a new item on a Current Report on Form 8-K.

285 See Deloitte, Risk INTElligent Proxy Disclosures-2011: HAVE Risk-Oversight PRACTICES IMPROVED? 3-5 (2011), available at http://www.deloitte.com/view/ en_US/us/Services/additional-services/governance-risk-compliance/40a7fb1b4c612310

VgnVCM3000001c56f00aRCRD.htm (listing out each studied consideration the subject of proxy disclosure on the board's role in overseeing the management of risk, as well as the percent of companies in the S\&P 200 reporting on each such consideration).
} 
evolved from year to year, as board practices evolve. ${ }^{286}$ There is every reason to believe that information about strategic management processes will become no more boilerplate than these equivalent disclosures about risk management processes.

Moreover, the benefit of such a rule may ultimately be not in the information that it provides, but in the processes that must be undertaken to make such disclosure. For example, while CEO and CFO certifications about the effectiveness of internal controls look the same from company to company, the value of such disclosure lies not in the company-specific information that is provided, but in the processes that must be undertaken to allow the CEO and CFO to provide such certifications in compliance with securities laws. This would also be true under my proposal, where disclosure about strategic management processes would help drive the firm's engagement in the underlying process. Thus, even if the new disclosure does look similar from company to company, it would largely still serve its intended function.

A final challenge to my proposal is that some firms might actually not be cognizant of their strategic management processes in place. That is especially true as to processes to ensure strategy implementation, which often involves employees throughout a firm.

This challenge actually supports the adoption of my proposal, for it is hard to imagine how a firm can improve its internal management processes to further profit-creation if it is not conscious of their existence or nature ${ }^{287}$ Thus, it is important for firms to be aware of those internal processes, not merely to comply with disclosure rules, but for the sake of fostering their own growth.

Still, the skeptic will undoubtedly want to consider alternative solutions to the problems I have raised.

One potential alternative solution is to scale back current risk management disclosure requirements so that there is balanced nondisclosure of both risk and strategic management processes. However, this solution would fail to capture a number of the benefits of my proposal. For one, while such a solution would provide a more balanced approach to risk and strategic management processes, it would fail to drive firms to engage in these valuable processes. It also would fail to push firms to perform risk and strategic management processes in a holistic, integrated fashion as encouraged by ERM. In addition, such an approach would fail to ensure investors received the information they needed to hold managers accountable for their risk and strategic management failings.

Still, it is arguable that without such regulation, firms would privately choose to provide such disclosure. However, the evidence belies this claim-

286 See id. at 5 (showing the changes in disclosure from 2010 to 2011 as to the considerations identified in the study).

287 See DAVILA ET AL., supra note 22, at 18. 
that is, companies currently do not voluntarily disclose virtually anything about their strategic management processes. ${ }^{288}$ In fact, numerous companies have tried to convince the SEC why they should not have to disclose their respective boards' roles in overseeing strategy in response to shareholder requests for this information. ${ }^{289}$ Thus, it is highly unlikely that if left unregulated, public firms would voluntarily disclose those aspects of their strategic and risk management processes that investors would need to make educated investment decisions or to hold managers accountable for performing these functions.

The other logical alternative is to more heavily regulate firms to force them to engage in strategic management processes. For example, firms could be required to engage in these two value-creating processes.

This potential solution also has a number of downsides. For one, to the extent this type of requirement specified how firms would need to manage their strategies, many of the benefits of strategic management would be lost. That is because there is no single "best" method. Rather, a firm's process depends on its type and size, among other factors. ${ }^{290}$ And even if current research suggested that there was a "best" method, mandating that all firms implement that method would prevent firms from experimenting and improving on those methods.

Alternatively, it is possible that firms could be required to engage in strategic management generally, without requiring them to implement any particular process. In fact, this is precisely what $I$ have proposed in a prior article. In that other article, I proposed modifying state fiduciary duty law so that officers and directors would be obligated to oversee their firm's strategic management process. ${ }^{291}$ I focused on state law because officers' and directors' responsibilities to their constituents are governed by state law. Thus state law is the legal schema in which we would expect to find such a duty, rather than federal securities laws, which typically regulate through disclosure mandates rather than conduct mandates. ${ }^{292}$

Still, as I discussed in Section IV.A. above, shareholders' ability to enforce that fiduciary duty is limited without information about what strategic management process management and the board are purporting to implement. Thus, my proposal in this article buttresses such a strategic management duty, but is not unnecessary because of it.

\footnotetext{
288 See discussion supra Section III.B.1.

289 See discussion supra Section III.B.1.

290 See DAVID, supra note 84, at 188, 213 (in terms of the formulation stage, noting a distinction between multidivisional firms and non-multidivisional firms as to which tools to use to help identify feasible alternative strategies, and in terms of the implementation stage, noting that strategy implementation varies substantially among different types and sizes of organization).

291 See Grossman, supra note 15 , at 508.

292 For a discussion of why such a duty should exist under state corporate law, see $i d$. at 49 -
} 51. 


\section{CONCLUSION}

From the throes of the financial crises of the twenty-first century has emerged a slew of laws and regulations focuses on curbing ill-advised risktaking. While those laws and regulations suggest that risk is managed in a vacuum, risk does not exist separate and apart from the strategy whence it emerged. And ignoring the strategic management process in those laws and regulations creates more problems than it solves. To truly empower investors to make better investment decisions and to hold managers accountable, they need information about processes to generate gains, to give context to and shed light on information they increasingly receive about processes to manage risk. That will ensure they see both sides of the coin in their effort to make that coin go further. 